\title{
Observation of atmospheric aerosols at Mt. Hua and Mt. Tai in central and east China during spring 2009 - Part 2: Impact of dust storm on organic aerosol composition and size distribution
}

\author{
G. H. Wang ${ }^{1,2}$, J. J. Li ${ }^{1}$, C. L. Cheng ${ }^{1}$, B. H. Zhou ${ }^{3}$, M. J. Xie ${ }^{4, *}$, S. Y. Hu${ }^{4}$, J. J. Meng ${ }^{1}$, T. Sun ${ }^{1}$, Y. Q. Ren ${ }^{1}$, J. J. Cao ${ }^{1}$, \\ S. X. Liu ${ }^{1}$, T. Zhang ${ }^{1}$, and Z. Z. Zhao ${ }^{1}$ \\ ${ }^{1}$ State Key Laboratory of Loess and Quaternary Geology, Institute of Earth Environment, Chinese Academy of Sciences, \\ Xi' an 710075, China \\ ${ }^{2}$ Department of Environmental Science, Xi' an Jiaotong University, Xi' an 710049, China \\ ${ }^{3}$ Department of Geographical Science and Environment Engineering, Baoji University of Art and Science, Baoji 721013, \\ China \\ ${ }^{4}$ State Key Laboratory of Pollution Control and Resources Reuse, School of the Environment, Nanjing University, Nanjing \\ 210093, China \\ *now at: University of Colorado, Boulder, USA
}

Correspondence to: G. H. Wang (wanggh@ieecas.cn, gehuiwang@yahoo.com.cn)

Received: 1 December 2011 - Published in Atmos. Chem. Phys. Discuss.: 20 December 2011

Revised: 2 April 2012 - Accepted: 17 April 2012 - Published: 8 May 2012

\begin{abstract}
PM}_{10}$ and size-resolved particles (9-stage) were simultaneously collected at Mt. Hua and Mt. Tai in central and east China during the spring of 2009 including a massive dust storm occurring on 24 April (named as DS II), and determined for organic compounds to investigate the impact of dust storm on organic aerosols. High molecular weight (HMW) $n$-alkanes, fatty acids, and fatty alcohols and trehalose sharply increased and almost entirely stayed in coarse particles when dust storm was present, suggesting that high level of organic aerosols in the mountain atmospheres during the event largely originated from Gobi desert plants. However, most anthropogenic aerosols (e.g. PAHs, and aromatic and dicarboxylic acids) during the event significantly decreased due to a dilution effect, indicating that anthropogenic aerosols in the mountain atmospheres during the nonevent period largely originated from local/regional sources rather than from long-range transport. Trehalose, a metabolism product enriched in biota in dry conditions, was $62 \pm 78$ and $421 \pm 181 \mathrm{ng} \mathrm{m}^{-3}$ at Mt. Hua and Mt. Tai during DS II, 10-30 times higher than that in the nonevent time, indicating that trehalose may be a tracer for dust emissions from Gobi desert regions. Molecular compositions of organic
\end{abstract}

aerosols in the mountain samples demonstrate that domestic coal burning is still the major source of PAHs in China.

$n$-Alkanes and fatty acids showed a bimodal size distribution during the nonevent with a major peak in fine mode $(<2.1 \mu \mathrm{m})$ and a small peak in coarse mode $(>2.1 \mu \mathrm{m})$. The coarse mode significantly increased and even dominated over the whole size range when dust was present. Glucose and trehalose were also dominant in the coarse mode especially in the DS II time. PAHs and levoglucosan concentrated in fine particles with no significant changes in size distribution when dust storm occurred. However, phthalic and succinic acids showed bimodal size distribution pattern with an increase in coarse mode during the event, because both are formed via a gas phase oxidation and a subsequent condensation/adsorption onto aerosol phase. In contrast, terephthalic and malic acids are mostly emitted from combustion process as fine particles, thus both showed a fine mode pattern during the whole campaign with a minor peak in coarse mode caused by an increased coagulation with dust during the event. Geometric mean diameters (GMDs) of the organic aerosols above are in general larger at Mt. Hua than at Mt. Tai during the nonevent period. We found that during the event GMD of the fine mode organics that derived mostly from 
the local/regional sources rather than Gobi desert became smaller while GMD of them in coarse mode became larger. Such a splitting in sizes during the event is most likely caused by decreased fine particle coagulation due to dilution and increased adsorption/coagulation with dust.

\section{Introduction}

Deserts and sandy lands in the northwest and north parts of China and the south part of Mongolia are the major source regions of Asia dust storm (Huebert et al., 2003; IPCC, 2007; Zhang et al., 2003). In each spring surface dusts in these areas are lifted up into the free troposphere by cold front systems and transported into the downwind regions including Pacific Ocean and North America (Seinfeld et al., 2004; Sullivan et al., 2007; Vancuren and Cahill, 2002). Recently satellite even observed that the Asia dust was transported more than one full circle around the globe within two weeks (Uno et al., 2009). Therefore, the Asia dust exerts a significant impact on climate and human health over the downwind regions, because during the long-range transport dust may react with numerous chemical species, coagulate with other particles, and provide reaction sites (Dunlea et al., 2009; Leaitch et al., 2009; Manktelow et al., 2010; Tobo et al., 2010).

Many researchers have focused on the impact of dust storm in East Asian on the downwind aerosol chemistry. Most of them are interested in inorganic components of the Asian aerosols such as elements (Arimoto et al., 2004), inorganic ions (Geng et al., 2009; Huang et al., 2010), elemental carbon (EC), organic carbon (OC), and inorganic gases such as $\mathrm{NO}_{\mathrm{x}}, \mathrm{SO}_{2}$ and $\mathrm{O}_{3}$ (Akimoto and Narita, 1994; Pathak et al., 2010). Only a few works considered the influence of the dust storm on organic aerosol chemistry (Simoneit et al., 2004a; Wang et al., 2009a), although OC mass was found to be abundant in the dust plume over the downwind regions (Wang et al., 2011d).

Atmospheric environment over mountain regions differs from that in urban and rural areas due to stronger solar radiation, lower temperature and higher relative humidity (Decesari et al., 2005; Li et al., 2011; Seinfeld and Pandis, 1998; Seinfeld et al., 2004). Moreover, particles in the mountain atmosphere are more significantly influenced by long-range transport, thus are indicative of the atmospheric characteristics on a large-scale (Decesari et al., 2005). Mt. Hua and Mt. Tai are located in central and east China, respectively. Ground surface level of $\mathrm{PM}_{2.5}$ in the above areas was found to be the highest in the world during 2001-2006 with an annual average of about $80 \mathrm{\mu g} \mathrm{m}^{-3}$ (van Donkelaar et al., 2010). $\mathrm{NO}_{\mathrm{x}}, \mathrm{SO}_{2}$ and dicarbonyls were also abundant in these regions (Akimoto, 2003; Akimoto and Narita, 1994; Fu et al., 2008a, c). These pollutants react and/or adsorb onto dust particles when dust storm presents and can be transported into the downstream regions. On 24 April 2009 a massive dust storm event originated from Gobi deserts (north China and Mongolia) simultaneously reached Mt. Hua and Mt. Tai, leading to a high level of dust layer covering the two mountain regions. In our previous paper we have reported the impact of the dust storm on EC, OC and inorganic ions in the atmospheres of Mt. Hua and Mt. Tai, and found a sharp increase in OC levels during the event (Wang et al., 2011c). In the current work we further compare the differences in molecular compositions of organic aerosols during the nondust storm and dust storm periods, and identify the changes in size distributions of the organic aerosols to investigate the impact of dust storm on the mountain aerosols. As far as we know, this is for the first time to present the direct evidence of the impact of dust storm on organic aerosol chemistry on a molecular level including composition and size distribution. We found that compared to those in the non-dust storm period sizes of primary organic aerosols derived from natural sources during the dust event became larger but those derived from anthropogenic sources including secondary organic aerosols became smaller. These results are useful for improving our understanding on the characters of Asian dust as it has been thought that aerosols become larger during dust storm episodes.

\section{Experimental section}

\subsection{Aerosol sampling}

Details of aerosol sample collection were reported elsewhere (Wang et al., 2011c). Briefly, $\mathrm{PM}_{10}$ and size-segregated aerosols were simultaneously collected at Mt. Hua $\left(34.48^{\circ} \mathrm{N}\right.$ and $\left.110.08^{\circ} \mathrm{E}\right)$ and $\mathrm{Mt}$ Tai $\left(36.27^{\circ} \mathrm{N}\right.$ and $\left.117.10^{\circ} \mathrm{E}\right)$ using a TC-100 sampler for $\mathrm{PM}_{10}$ and a 9-stage sampler for the size-resolved samples. The summits of Mt. Hua and Mt. Tai are $2060 \mathrm{~m}$ and $1545 \mathrm{~m}$ above sea level, respectively, and the sampler inlets are around 3-5 $\mathrm{m}$ above the ground. Mt. Hua is located in Guanzhong Basin, central China and Mt. Tai is situated in North China Plain, east China (see Fig. 1). Airflow rate of the $\mathrm{PM}_{10}$ sampler is $1001 \mathrm{~min}^{-1}$, while that of the 9-stage sampler is $28.31 \mathrm{~min}^{-1}$ with the 9 size bins as $<0.4 \mu \mathrm{m}, 0.4-0.7 \mu \mathrm{m}, 0.7-1.1 \mu \mathrm{m}, 1.1-2.1 \mu \mathrm{m}, 2.1-3.3 \mu \mathrm{m}$, 3.3-4.7 $\mu \mathrm{m}, 4.7-5.8 \mu \mathrm{m}, 5.8-9.0 \mu \mathrm{m}$ and $>9.0 \mu \mathrm{m}$. Particles were collected onto pre-combusted quartz filters $\left(450^{\circ} \mathrm{C}\right.$ for $8 \mathrm{~h}$ ). The samplings at both mountain sites were performed from 27 March to 30 April 2009. Each PM $_{10}$ sample was collected for $24 \mathrm{~h}$, while each set of the size-segregated samples was collected for 4-6 days. Field blank samples were also collected before and after the sampling. During the campaign a mild dust storm from Gobi desert reached Mt. Hua on 20 April (named as DS I, hereinafter), and four days later a heavy dust storm, which also originated from Gobi desert, simultaneously arrived in Mt. Hua and Mt. Tai (named as DS II, hereinafter). During the DS II event $\mathrm{PM}_{10}$ collection was changed as 3-6h depending on the particle loading, while the 


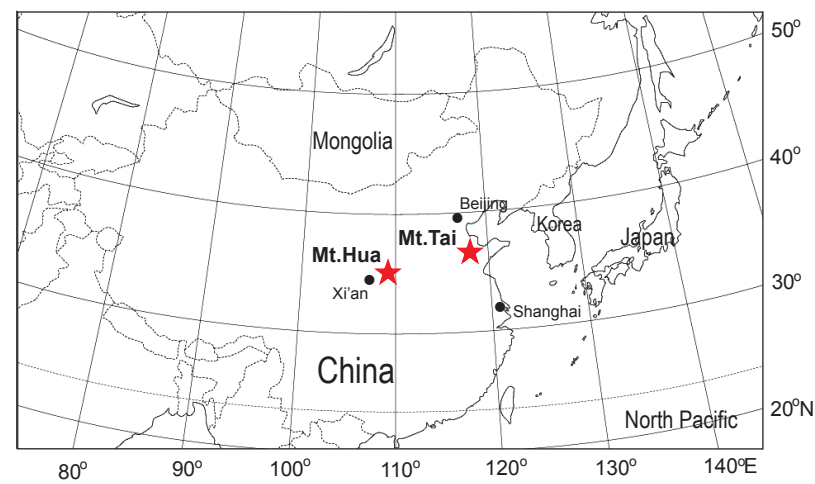

Fig. 1. A map description for the sampling locations (Mt. Hua and Mt. Tai) and their surroundings.

size-resolved sampling was changed as one day. Due to the 9-stage instrument problem the size-resolved sampling during DS II at Mt. Tai was stopped. After sampling, the samples were sealed in aluminum foil bags and stored in freezer under $-20^{\circ} \mathrm{C}$ prior to analysis.

\subsection{Organic aerosol analysis}

Aliquot of the filter was cut in pieces and extracted with a mixture of methanol and dichloromethane, then concentrated into dryness and reacted with BSTFA. Organic compounds in the derivatized sample was determined using GC/MS. Recoveries of the target compounds were better than $80 \%$, and no contamination was found in the blanks. Detailed information about the organic compound quantification can be seen in Wang et al. (2011a). A strong linear correlation was obtained for the organic compounds measured by the $\mathrm{PM}_{10}$ and the 9-stage samplers with a slope close to unity (Fig. 2), indicating a good agreement between the two data sets. EC, OC and inorganic ions of the samples were reported elsewhere (Wang et al., 2011c), and cited here for discussion.

\section{Results and discussions}

\subsection{Concentrations, molecular compositions and sources}

A total of seven classes of organic compounds, i.e. $n$-alkanes, fatty acids, fatty alcohols, polycyclic aromatic hydrocarbons (PAHs), sugars, aromatic acids and dicarboxylic acids in the $\mathrm{PM}_{10}$ samples were determined and summarized in Table 1. During the spring non-dust storm period (NDS), all the determined organics in $\mathrm{PM}_{10}$ were $522 \pm 164 \mathrm{ng} \mathrm{m}^{-3}$ at Mt. Hua and $1147 \pm 421 \mathrm{ng} \mathrm{m}^{-3}$ at Mt. Tai, respectively (Table 1). In contrast, the total organics during DS I and DS II were $865 \mathrm{ng} \mathrm{m}^{-3}$ and $1299 \mathrm{ng} \mathrm{m}^{-3}$ at Mt. Hua and $1753 \mathrm{ng} \mathrm{m}^{-3}$ during DS II at Mt. Tai. Temporal variations of OC and EC showed that OC sharply increased as much as $30 \mu \mathrm{g} \mathrm{m}^{-3}$ at

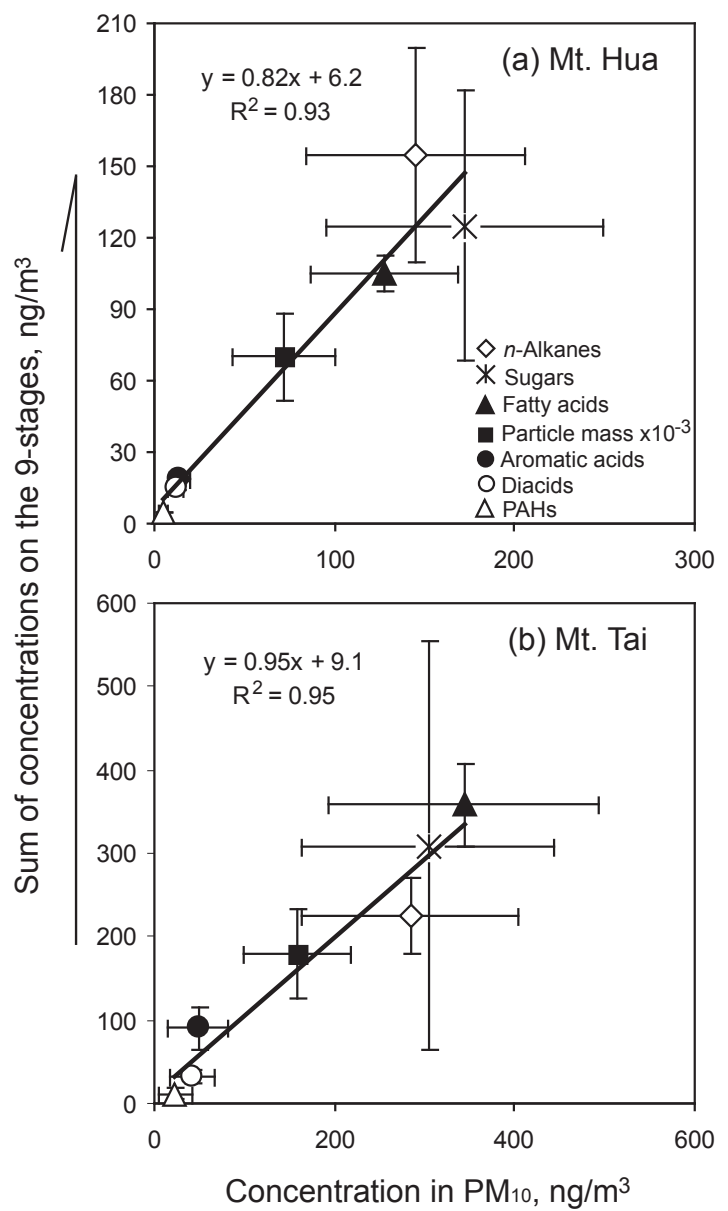

Fig. 2. An intercomparison of compound concentrations measured in the $\mathrm{PM}_{10}$ and the size-segregated samples.

Mt. Hua and $52 \mu \mathrm{g} \mathrm{m}^{-3}$ at Mt. Tai during DS II, respectively (Fig. 3a, b). However, EC significantly decreased at both sites during the event (Fig. 3), suggesting that the dust storm event imported organic aerosols and diluted local pollutants. During the nonevent $\mathrm{OC}$ and $\mathrm{EC}$ in the $\mathrm{PM}_{10}$ of Mt. Tai were $13 \pm 5.9$ and $2.8 \pm 2.1 \mu \mathrm{g} \mathrm{m}^{-3}$, respectively, two times more abundant than those from Mt. Hua, indicating that the Mt. Tai air is more polluted. One possible reason is the lower altitude of Mt. Tai, which is more accessible for lowland pollutants.

\subsection{1 n-Alkanes, fatty acids and fatty alcohols}

Total $n$-alkanes in $\mathrm{PM}_{10}$ during NDS period were found to be $145 \pm 61$ and $284 \pm 120 \mathrm{ng} \mathrm{m}^{-3}$ at Mt. Hua and Mt. Tai with the maximal homologues of $\mathrm{C}_{31}$ at Mt. Hua and $\mathrm{C}_{29}$ at Mt. Tai (Table 1 and Fig. 4a), which is mainly due to the different plant compositions. For example, $n$-alkanes from wheat, straw and other herbages are in general dominated by $\mathrm{C}_{29}$, followed by $\mathrm{C}_{31}$; while those from trees are generally dominated by $\mathrm{C}_{31}$, followed by $\mathrm{C}_{29}$ (Wang et al., 2009c). Atmospheric $n$-alkanes can be emitted from leaf surface due 
Table 1. Concentrations of organic compounds in $\mathrm{PM}_{10}$ collected at the summits of Mt. Hua (2060 m a.s.1.) and Mt. Tai (1545 ma.s.1.) in central and east China during spring $2009\left(\mathrm{ng} \mathrm{m}^{-3}\right)$.

\begin{tabular}{|c|c|c|c|c|c|c|c|c|c|c|c|c|c|c|c|c|c|}
\hline & \multicolumn{9}{|c|}{ Mt. Hua } & \multicolumn{8}{|c|}{ Mt. Tai } \\
\hline & \multicolumn{4}{|c|}{ Non-dust storm $(n=31)$} & \multirow{2}{*}{ Dust storm I $(n=1)$} & \multicolumn{4}{|c|}{ Dust storm II $(n=2)$} & Nor & -dust st & $\operatorname{rrm}(n=$ & & & ist stor & II $(n=$ & \\
\hline & Min & $\operatorname{Max}$ & Mean & Std & & Min & $\operatorname{Max}$ & Mean & Std & Min & Max & Mean & Std & Min & $\operatorname{Max}$ & Mean & Std \\
\hline I. $n$-Alkanes & & & & & & & & & & & & & & & & & \\
\hline $\mathrm{C}_{18}$ & 0.3 & 0.9 & 0.5 & 0.2 & 0.5 & 0.5 & 1.4 & 1.0 & 0.6 & 0.2 & 2.1 & 1.1 & 0.5 & 1.4 & 2.4 & 1.9 & 0.5 \\
\hline $\mathrm{C}_{19}$ & 0.2 & 0.7 & 0.5 & 0.1 & 0.5 & 0.9 & 1.2 & 1.0 & 0.2 & 0.2 & 3.1 & 1.2 & 0.6 & 1.9 & 3.4 & 2.8 & 0.8 \\
\hline $\mathrm{C}_{20}$ & 0.2 & 1.1 & 0.5 & 0.2 & 0.4 & 0.9 & 1.3 & 1.1 & 0.3 & 0.2 & 3.8 & 1.3 & 0.8 & 3.0 & 3.3 & 3.1 & 0.2 \\
\hline $\mathrm{C}_{21}$ & 0.4 & 3.0 & 1.4 & 0.5 & 1.3 & 2.2 & 2.2 & 2.2 & 0.0 & 0.5 & 8.8 & 2.8 & 1.8 & 5.8 & 6.5 & 6.2 & 0.4 \\
\hline $\mathrm{C}_{22}$ & 0.3 & 4.8 & 1.5 & 0.8 & 1.0 & 1.7 & 1.8 & 1.8 & 0.1 & 0.6 & 9.2 & 3.1 & 2.1 & 3.7 & 4.4 & 4.0 & 0.3 \\
\hline $\mathrm{C}_{23}$ & 0.8 & 8.2 & 3.2 & 1.6 & 2.7 & 4.6 & 4.6 & 4.6 & 0.0 & 1.4 & 13 & 5.8 & 3.0 & 6.6 & 7.5 & 7.1 & 0.5 \\
\hline $\mathrm{C}_{24}$ & 0.8 & 7.2 & 2.7 & 1.6 & 2.0 & 2.7 & 3.7 & 3.2 & 0.7 & 1.5 & 13 & 5.4 & 3.2 & 4.7 & 6.4 & 5.5 & 0.8 \\
\hline $\mathrm{C}_{25}$ & 2.2 & 14 & 5.4 & 2.8 & 8.2 & 11 & 15 & 13 & 2.8 & 1.9 & 20 & 10 & 4.6 & 8.6 & 14 & 12 & 2.8 \\
\hline $\mathrm{C}_{26}$ & 1.3 & 9.7 & 3.6 & 2.0 & 5.0 & 4.3 & 11 & 7.8 & 5.0 & 1.1 & 17 & 8.0 & 4.2 & 4.7 & 8.3 & 6.9 & 1.9 \\
\hline $\mathrm{C}_{27}$ & 4.5 & 29 & 12 & 6.6 & 34 & 50 & 67 & 59 & 12 & 2.5 & 73 & 25 & 14 & 27 & 52 & 43 & 14 \\
\hline $\mathrm{C}_{28}$ & 2.3 & 12 & 5.2 & 2.5 & 13 & 7.3 & 39 & 23 & 22 & 1.0 & 23 & 12 & 5.6 & 6.1 & 14 & 11 & 4.4 \\
\hline $\mathrm{C}_{29}$ & 8.0 & 64 & 29 & 14 & 88 & 113 & 159 & 136 & 33 & 2.8 & 189 & 57 & 34 & 63 & 143 & 110 & 42 \\
\hline $\mathrm{C}_{30}$ & 2.8 & 15 & 6.2 & 3.0 & 20 & 9.4 & 60 & 35 & 36 & 0.9 & 30 & 14 & 7.3 & 5.8 & 14 & 10 & 4.0 \\
\hline $\mathrm{C}_{31}$ & 7.9 & 77 & 31 & 14 & 77 & 126 & 148 & 137 & 15 & 3.4 & 86 & 45 & 18 & 101 & 206 & 162 & 55 \\
\hline $\mathrm{C}_{32}$ & 2.3 & 13 & 5.3 & 2.5 & 20 & 7.7 & 50 & 29 & 30 & 0.6 & 32 & 13 & 7.3 & 6.3 & 11 & 8.7 & 2.3 \\
\hline $\mathrm{C}_{33}$ & 4.3 & 45 & 20 & 9.1 & 48 & 61 & 102 & 81 & 29 & 1.4 & 78 & 31 & 17 & 30 & 55 & 46 & 13 \\
\hline $\mathrm{C}_{34}$ & 1.9 & 14 & 4.8 & 2.4 & 18 & 8.8 & 34 & 21 & 17 & 0.9 & 31 & 12 & 7.5 & 6.6 & 7.9 & 7.1 & 0.7 \\
\hline $\mathrm{C}_{35}$ & 2.1 & 22 & 8.6 & 3.9 & 30 & 15 & 46 & 30 & 22 & 2.3 & 61 & 24 & 14 & 18 & 23 & 21 & 2.4 \\
\hline $\mathrm{C}_{36}$ & 1.1 & 13 & 4.4 & 2.1 & 14 & 8.6 & 20 & 14 & 8 & 0.8 & 38 & 13 & 8.6 & 2.0 & 15 & 9.3 & 6.6 \\
\hline Subtotal & 48 & 297 & 145 & 61 & 383 & 436 & 767 & 602 & 234 & 29 & 581 & 284 & 120 & 308 & 584 & 477 & 148 \\
\hline Plant wax $n$-alkanes & 13 & 159 & 78 & 38 & 203 & 334 & 337 & 336 & 1.6 & 9.5 & 371 & 128 & 69 & 217 & 441 & 347 & 116 \\
\hline Fossil fuel $n$-alkanes & 28 & 144 & 67 & 29 & 180 & 100 & 432 & 266 & 235 & 19 & 380 & 155 & 85 & 91 & 156 & 130 & 34 \\
\hline CPI & 1.8 & 7.2 & 3.3 & 1.1 & 3.1 & 2.5 & 7.4 & 5.0 & 3.5 & 1.7 & 8.6 & 3.0 & 1.7 & 5.7 & 7.0 & 6.2 & 0.7 \\
\hline II. Fatty acids & & & & & & & & & & & & & & & & & \\
\hline $\mathrm{C}_{10: 0}$ & 0.8 & 4.3 & 2.2 & 0.8 & 1.9 & 2.0 & 4.2 & 3.1 & 1.6 & 0.3 & 6.3 & 2.0 & 1.3 & 2.3 & 5.2 & 3.7 & 1.4 \\
\hline $\mathrm{C}_{11: 0}$ & 0.6 & 4.8 & 1.9 & 0.9 & 2.4 & 1.3 & 2.3 & 1.8 & 0.7 & 0.2 & 4.5 & 2.2 & 1.1 & 1.8 & 3.8 & 2.6 & 1.1 \\
\hline $\mathrm{C}_{12: 0}$ & 1.0 & 4.1 & 2.4 & 0.8 & 2.0 & 1.6 & 1.7 & 1.6 & 0.0 & 0.3 & 5.8 & 2.9 & 1.4 & 2.5 & 5.2 & 4.1 & 1.4 \\
\hline $\mathrm{C}_{13: 0}$ & 0.8 & 3.6 & 1.9 & 0.6 & 1.5 & 1.6 & 1.8 & 1.7 & 0.2 & 0.3 & 7.6 & 3.7 & 1.9 & 2.1 & 3.4 & 2.7 & 0.6 \\
\hline $\mathrm{C}_{14: 0}$ & 1.7 & 5.3 & 2.7 & 0.9 & 3.8 & 3.0 & 3.9 & 3.5 & 0.7 & 0.5 & 12 & 6.2 & 2.8 & 5.5 & 21 & 12 & 8.2 \\
\hline $\mathrm{C}_{15: 0}$ & 0.4 & 2.6 & 1.4 & 0.5 & 1.3 & 1.3 & 1.8 & 1.6 & 0.3 & 0.2 & 9.7 & 3.8 & 1.9 & 3.2 & 3.5 & 3.4 & 0.2 \\
\hline $\mathrm{C}_{16: 0}$ & 12 & 45 & 25 & 7.0 & 31 & 43 & 96 & 66 & 36 & 9.0 & 198 & 96 & 43 & 90 & 132 & 114 & 21 \\
\hline $\mathrm{C}_{17: 0}$ & 0.4 & 1.2 & 0.8 & 0.2 & 0.7 & 1.0 & 1.3 & 1.1 & 0.2 & 0.1 & 4.5 & 2.5 & 1.2 & 1.6 & 2.0 & 1.9 & 0.2 \\
\hline $\mathrm{C}_{18: 1}$ & 0.9 & 6.7 & 3.1 & 1.6 & 5.0 & 7.1 & 26 & 17 & 14 & 1.0 & 18 & 9.9 & 4.6 & 8.7 & 11 & 10 & 1.4 \\
\hline $\mathrm{C}_{18: 0}$ & 5.8 & 24 & 14 & 4.0 & 17 & 34 & 36 & 35 & 1.4 & 3.2 & 118 & 51 & 25 & 42 & 65 & 56 & 12 \\
\hline $\mathrm{C}_{19: 0}$ & 0.6 & 2.5 & 1.7 & 0.5 & 1.8 & 1.5 & 2.6 & 2.1 & 0.8 & 0.3 & 12 & 5.4 & 3.3 & 2.6 & 3.5 & 3.2 & 0.5 \\
\hline $\mathrm{C}_{20: 0}$ & 1.1 & 9.0 & 4.5 & 1.6 & 5.2 & 5.5 & 13 & 9.0 & 5.0 & 0.8 & 19 & 11 & 5.1 & 5.8 & 11 & 8.6 & 2.8 \\
\hline $\mathrm{C}_{21: 0}$ & 0.4 & 3.6 & 2.0 & 0.7 & 1.9 & 1.5 & 4.1 & 2.8 & 1.8 & 0.4 & 10 & 5.3 & 2.7 & 2.6 & 4.5 & 3.7 & 1.0 \\
\hline $\mathrm{C}_{22: 0}$ & 1.2 & 46 & 7.9 & 7.5 & 6.8 & 9.1 & 22 & 16 & 9.4 & 1.2 & 60 & 22 & 15 & 17 & 56 & 30 & 22 \\
\hline $\mathrm{C}_{23: 0}$ & 0.8 & 16 & 6.1 & 2.9 & 16 & 5.8 & 8.4 & 7.1 & 1.8 & 0.4 & 26 & 11 & 6.5 & 3.1 & 4.0 & 3.4 & 0.5 \\
\hline $\mathrm{C}_{24: 0}$ & 1.6 & 16 & 9.5 & 3.6 & 12 & 11 & 34 & 22 & 16 & 1.4 & 44 & 21 & 11 & 11 & 34 & 22 & 11 \\
\hline $\mathrm{C}_{25: 0}$ & 0.4 & 5.0 & 2.6 & 1.1 & 2.5 & 2.2 & 6.6 & 4.4 & 3.1 & 0.6 & 13 & 6.4 & 3.4 & 3.1 & 5.8 & 4.6 & 1.3 \\
\hline $\mathrm{C}_{26: 0}$ & 0.8 & 15 & 7.7 & 3.5 & 12 & 12 & 31 & 21 & 13 & 0.8 & 33 & 15 & 8.0 & 7.6 & 24 & 15 & 8.2 \\
\hline $\mathrm{C}_{27: 0}$ & 0.3 & 4.4 & 2.2 & 1.0 & 2.6 & 2.2 & 7.2 & 4.7 & 3.5 & 0.6 & 12 & 5.7 & 3.2 & 2.9 & 6.9 & 4.7 & 2.0 \\
\hline $\mathrm{C}_{28: 0}$ & 0.8 & 19 & 9.3 & 4.6 & 16 & 15 & 52 & 34 & 26 & 1.1 & 41 & 18 & 10 & 15 & 42 & 27 & 14 \\
\hline $\mathrm{C}_{29: 0}$ & 0.5 & 4.6 & 2.6 & 1.0 & 3.9 & 4.8 & 9.8 & 7.3 & 3.5 & 0.7 & 11 & 6.7 & 3.3 & 3.8 & 9.4 & 6.8 & 2.8 \\
\hline $\mathrm{C}_{30: 0}$ & 1.0 & 18 & 9.5 & 4.5 & 14 & 13 & 59 & 36 & 33 & 1.7 & 42 & 20 & 11 & 18 & 58 & 37 & 20 \\
\hline $\mathrm{C}_{31: 0}$ & 0.5 & 5.3 & 2.4 & 1.1 & 4.4 & 4.4 & 9.4 & 6.9 & 3.5 & 0.9 & 15 & 7.5 & 4.0 & 8.5 & 10 & 9.4 & 0.9 \\
\hline $\mathrm{C}_{32: 0}$ & 0.5 & 6.9 & 3.4 & 1.5 & 3.6 & 5.1 & 17 & 11 & 8.6 & 1.1 & 23 & 9.0 & 4.8 & 8.6 & 21 & 14 & 6.4 \\
\hline Subtotal & 29 & 214 & 128 & 41 & 169 & 265 & 372 & 319 & 75 & 29 & 690 & 344 & 150 & 272 & 541 & 398 & 135 \\
\hline CPI & 3.0 & 5.7 & 4.0 & 0.7 & 3.2 & 5.8 & 7.2 & 6.5 & 1.0 & 3.1 & 9.3 & 4.9 & 1.3 & 6.3 & 8.3 & 7.1 & 1.0 \\
\hline III. Fatty alcohols & & & & & & & & & & & & & & & & & \\
\hline $\mathrm{C}_{20}$ & 0.4 & 1.5 & 0.8 & 0.3 & 0.7 & 0.9 & 1.6 & 1.2 & 0.5 & 0.3 & 6.9 & 2.6 & 1.5 & 0.8 & 3.7 & 2.1 & 1.5 \\
\hline $\mathrm{C}_{21}$ & 0.3 & 2.2 & 0.9 & 0.4 & 0.9 & 0.9 & 1.3 & 1.1 & 0.3 & 0.3 & 5.7 & 2.7 & 1.5 & 1.2 & 1.8 & 1.4 & 0.3 \\
\hline $\mathrm{C}_{22}$ & 0.4 & 3.1 & 1.5 & 0.6 & 2.2 & 2.6 & 5.3 & 4.0 & 1.9 & 0.5 & 8.2 & 4.1 & 1.6 & 2.5 & 5.7 & 4.5 & 1.7 \\
\hline $\mathrm{C}_{23}$ & 0.2 & 4.5 & 1.9 & 1.1 & 1.5 & 1.2 & 1.6 & 1.4 & 0.3 & 0.4 & 6.4 & 3.6 & 1.7 & 2.2 & 2.9 & 2.5 & 0.4 \\
\hline $\mathrm{C}_{24}$ & 0.5 & 6.6 & 3.0 & 1.7 & 6.1 & 8.5 & 15 & 12 & 4.6 & 0.5 & 10 & 5.5 & 2.2 & 18 & 30 & 24 & 5.6 \\
\hline $\mathrm{C}_{25}$ & 0.3 & 2.3 & 1.1 & 0.5 & 1.3 & 1.4 & 2.4 & 1.9 & 0.7 & 0.4 & 8.0 & 3.5 & 1.9 & 1.6 & 3.1 & 2.5 & 0.8 \\
\hline $\mathrm{C}_{26}$ & 0.6 & 28 & 7.9 & 5.8 & 13 & 15 & 32 & 24 & 12 & 0.6 & 25 & 11 & 5.4 & 7.2 & 23 & 16 & 8.2 \\
\hline $\mathrm{C}_{27}$ & 0.3 & 2.5 & 1.2 & 0.5 & 1.3 & 1.8 & 2.8 & 2.3 & 0.7 & 0.4 & 9.5 & 3.7 & 2.3 & 2.5 & 3.7 & 3.1 & 0.6 \\
\hline $\mathrm{C}_{28}$ & 0.8 & 60 & 13 & 12 & 28 & 19 & 59 & 39 & 28 & 1.4 & 91 & 29 & 22 & 32 & 89 & 63 & 29 \\
\hline $\mathrm{C}_{29}$ & 0.5 & 4.7 & 1.9 & 0.8 & 2.5 & 3.5 & 6.2 & 4.9 & 1.9 & 0.7 & 12 & 5.3 & 2.6 & 3.3 & 7.1 & 5.4 & 1.9 \\
\hline $\mathrm{C}_{30}$ & 0.8 & 10 & 4.8 & 2.3 & 11 & 11 & 33 & 22 & 15 & 1.2 & 30 & 15 & 7.7 & 19 & 53 & 35 & 17 \\
\hline $\mathrm{C}_{31}$ & 0.7 & 6.2 & 2.6 & 1.5 & 4.3 & 4.1 & 5.1 & 4.6 & 0.7 & 0.6 & 21 & 6.9 & 3.9 & 8.0 & 17 & 11 & 5.2 \\
\hline $\mathrm{C}_{32}$ & 0.6 & 5.3 & 2.4 & 1.1 & 3.8 & 5.9 & 17 & 11 & 7.7 & 0.7 & 17 & 7.7 & 3.6 & 12 & 15 & 13 & 1.6 \\
\hline Subtotal & 6.6 & 104 & 43 & 22 & 76 & 77 & 182 & 129 & 74 & 8.1 & 196 & 100 & 48 & 110 & 249 & 185 & 70 \\
\hline CPI & 1.5 & 14 & 3.6 & 2.5 & 5.4 & 4.9 & 8.3 & 6.6 & 2.4 & 1.5 & 8.2 & 3.0 & 1.5 & 4.8 & 7.2 & 6.0 & 1.2 \\
\hline
\end{tabular}


Table 1. Continued.

\begin{tabular}{|c|c|c|c|c|c|c|c|c|c|c|c|c|c|c|c|c|c|}
\hline & \multicolumn{9}{|c|}{ Mt. Hua } & \multicolumn{8}{|c|}{ Mt. Tai } \\
\hline & \multicolumn{4}{|c|}{ Non-dust storm $(n=31)$} & \multirow[t]{2}{*}{ Dust storm I $(n=1)$} & \multicolumn{4}{|c|}{ Dust storm II $(n=2)$} & \multicolumn{4}{|c|}{ Non-dust storm $(n=29)$} & \multicolumn{4}{|c|}{ Dust storm II $(n=3)$} \\
\hline & Min & $\operatorname{Max}$ & Mean & Std & & Min & $\operatorname{Max}$ & Mean & Std & Min & $\operatorname{Max}$ & Mean & Std & Min & $\operatorname{Max}$ & Mean & Std \\
\hline \multicolumn{18}{|l|}{ IV. PAHs } \\
\hline Phe & 0.2 & 1.0 & 0.6 & 0.2 & 0.5 & 0.9 & 1.2 & 1.1 & 0.2 & 0.1 & 3.8 & 1.0 & 1.0 & 0.4 & 0.6 & 0.5 & 0.1 \\
\hline Ant & 0.1 & 0.6 & 0.3 & 0.1 & 0.3 & 0.2 & 0.3 & 0.3 & 0.1 & 0.1 & 4.1 & 1.3 & 1.0 & 0.3 & 0.5 & 0.4 & 0.1 \\
\hline Flu & 0.3 & 1.2 & 0.7 & 0.2 & 0.8 & 1.1 & 1.3 & 1.2 & 0.1 & 0.2 & 5.2 & 1.7 & 1.3 & 0.8 & 1.3 & 1.1 & 0.3 \\
\hline Pyr & 0.1 & 0.8 & 0.4 & 0.2 & 0.5 & 0.5 & 0.6 & 0.5 & 0.1 & 0.1 & 4.6 & 1.5 & 1.1 & 0.5 & 1.0 & 0.8 & 0.3 \\
\hline $\mathrm{BaA}$ & 0.0 & 0.5 & 0.2 & 0.1 & 0.2 & 0.1 & 0.3 & 0.2 & 0.1 & 0.2 & 5.2 & 2.0 & 1.6 & 0.4 & 0.8 & 0.5 & 0.2 \\
\hline $\mathrm{CT}$ & 0.1 & 1.1 & 0.5 & 0.3 & 0.7 & 0.5 & 0.8 & 0.6 & 0.3 & 0.1 & 13 & 2.7 & 3.3 & 0.5 & 0.7 & 0.6 & 0.1 \\
\hline BbkF & 0.2 & 1.6 & 0.7 & 0.4 & 0.9 & 0.3 & 1.3 & 0.8 & 0.7 & 0.1 & 9.2 & 3.2 & 2.3 & 1.1 & 2.4 & 1.7 & 0.7 \\
\hline $\mathrm{BeP}$ & 0.1 & 1.1 & 0.5 & 0.3 & 0.7 & 0.4 & 1.0 & 0.7 & 0.4 & 0.1 & 10 & 2.6 & 2.6 & 0.5 & 1.4 & 0.9 & 0.5 \\
\hline $\mathrm{BaP}$ & 0.1 & 0.8 & 0.3 & 0.2 & 0.4 & 0.2 & 0.4 & 0.3 & 0.2 & 0.1 & 4.7 & 1.7 & 1.4 & 0.4 & 0.8 & 0.6 & 0.2 \\
\hline Per & 0.0 & 0.2 & 0.1 & 0.1 & 0.2 & 0.1 & 0.1 & 0.1 & 0.0 & 0.0 & 4.1 & 1.1 & 1.1 & 0.4 & 0.7 & 0.5 & 0.2 \\
\hline IP & 0.1 & 1.3 & 0.6 & 0.3 & 0.6 & 0.2 & 0.8 & 0.5 & 0.4 & 0.1 & 7.5 & 2.6 & 2.1 & 0.1 & 0.7 & 0.4 & 0.3 \\
\hline BghiP & 0.0 & 0.5 & 0.3 & 0.1 & 0.3 & 0.2 & 0.5 & 0.4 & 0.2 & 0.1 & 3.0 & 1.1 & 0.8 & 0.2 & 0.5 & 0.3 & 0.1 \\
\hline DBA & 0.0 & 0.3 & 0.1 & 0.1 & 0.2 & 0.1 & 0.3 & 0.2 & 0.1 & 0.0 & 4.1 & 1.0 & 1.0 & 0.0 & 0.2 & 0.1 & 0.1 \\
\hline Subtotal & 1.5 & 10 & 5.3 & 2.3 & 6.5 & 5.5 & 8.4 & 7.0 & 2.0 & 1.6 & 75 & 23 & 19 & 5.7 & 11 & 8.4 & 2.8 \\
\hline \multicolumn{18}{|l|}{ V. Sugars } \\
\hline Galactosan & 1.2 & 9.9 & 4.8 & 2.2 & 3.3 & 3.5 & 5.2 & 4.4 & 1.2 & 0.2 & 29 & 14 & 7.8 & 7.9 & 21 & 15 & 6.6 \\
\hline Mannosan & 1.2 & 30 & 5.0 & 4.9 & 2.8 & 3.6 & 4.6 & 4.1 & 0.7 & 0.1 & 27 & 11 & 6.1 & 7.8 & 17 & 13 & 4.7 \\
\hline Levoglucosan & 13 & 106 & 48 & 20 & 25 & 27 & 44 & 36 & 12 & 0.2 & 385 & 158 & 95 & 62 & 142 & 110 & 43 \\
\hline Fructose & 1.0 & 20 & 6.3 & 4.7 & 6.8 & 7.7 & 8.8 & 8.2 & 0.8 & 0.0 & 68 & 13 & 12 & 6.4 & 17 & 11 & 5.3 \\
\hline Glucose & 1.4 & 39 & 11 & 9.3 & 9.7 & 9.0 & 16 & 12 & 4.8 & 0.5 & 85 & 22 & 18 & 26 & 69 & 48 & 21 \\
\hline Arabitol & 3.2 & 45 & 17 & 11 & 26 & 17 & 23 & 20 & 4.0 & 0.1 & 68 & 23 & 17 & 6.4 & 11 & 9.0 & 2.4 \\
\hline Mannito 1 & 0.4 & 16 & 4.8 & 3.7 & 6.1 & 4.6 & 6.3 & 5.4 & 1.2 & 0.3 & 254 & 15 & 46 & 1.5 & 3.3 & 2.4 & 0.9 \\
\hline Inositol & 0.2 & 1.5 & 0.6 & 0.3 & 0.7 & 0.2 & 0.4 & 0.3 & 0.1 & 0.0 & 2.3 & 1.2 & 0.5 & 0.8 & 1.5 & 1.1 & 0.4 \\
\hline Sucrose & 1.5 & 193 & 69 & 55 & 110 & 63 & 97 & 80 & 24 & 0.1 & 151 & 36 & 38 & 22 & 88 & 50 & 34 \\
\hline Trehalose & 0.5 & 24 & 6.2 & 4.9 & 35 & 7.1 & 118 & 62 & 78 & 0.4 & 96 & 13 & 19 & 231 & 592 & 421 & 181 \\
\hline Subtotal & 26 & 359 & 172 & 77 & 225 & 184 & 281 & 233 & 69 & 3.8 & 561 & 304 & 140 & 372 & 960 & 680 & 295 \\
\hline \multicolumn{18}{|c|}{ VI. Aromatic acids } \\
\hline Phthalic & 0.6 & 20 & 8.4 & 4.0 & 1.3 & 1.0 & 7.3 & 4.2 & 4.5 & 0.1 & 69 & 25 & 16 & 0.6 & 1.2 & 1.0 & 0.4 \\
\hline Isophthalic & 0.1 & 0.8 & 0.4 & 0.2 & 0.1 & 0.1 & 0.1 & 0.1 & 0.0 & 0.0 & 5.8 & 1.3 & 1.1 & 0.2 & 0.2 & 0.2 & 0.0 \\
\hline Terephthalic & 1.0 & 14 & 4.7 & 2.9 & 1.5 & 1.0 & 1.3 & 1.1 & 0.2 & 0.1 & 74 & 23 & 19 & 1.3 & 1.5 & 1.4 & 0.1 \\
\hline Subtotal & 2.4 & 26 & 14 & 5.3 & 2.9 & 2.4 & 8.4 & 5.4 & 4.3 & 0.2 & 145 & 49 & 34 & 2.2 & 2.9 & 2.6 & 0.4 \\
\hline \multicolumn{18}{|l|}{ VII. Diacids } \\
\hline Succinic acid & 1.1 & 12 & 7.1 & 2.3 & 1.8 & 1.1 & 4.2 & 2.7 & 2.2 & 0.2 & 60 & 24 & 15 & 1.7 & 2.5 & 2.1 & 0.4 \\
\hline Glutaric acid & 0.3 & 3.3 & 1.7 & 0.8 & 0.7 & 0.3 & 0.9 & 0.6 & 0.4 & 0.2 & 11 & 3.9 & 2.5 & 0.5 & 0.9 & 0.8 & 0.2 \\
\hline Malic acid & 0.4 & 7.4 & 2.9 & 1.8 & 0.8 & 0.7 & 1.7 & 1.2 & 0.7 & 0.2 & 18 & 5.7 & 4.5 & 1.3 & 1.9 & 1.6 & 0.3 \\
\hline Subtotal & 1.8 & 22 & 12 & 4.4 & 3.4 & 2.2 & 6.9 & 4.5 & 3.3 & 1.4 & 102 & 42 & 25 & 3.7 & 5.3 & 4.5 & 0.8 \\
\hline Total & 126 & 852 & 522 & 164 & 865 & 1240 & 1304 & 1299 & 6.2 & 148 & 2001 & 1147 & 421 & 995 & 2238 & 1753 & 626 \\
\hline Total/OC, $\%$ & 5.6 & 18 & 10 & 2.9 & 11 & 4.1 & 7.6 & 5.6 & 2.5 & 3.4 & 17 & 8.8 & 2.8 & 4.1 & 4.6 & 4.4 & 0.1 \\
\hline $\mathrm{PM}_{10}\left(\mu \mathrm{g} \mathrm{m}^{-3}\right)$ & 24 & 135 & 72 & 28 & 173 & 272 & 740 & 506 & 331 & 31 & 261 & 159 & 60 & 898 & 1797 & 1343 & 450 \\
\hline $\mathrm{OC}\left(\mu \mathrm{g} \mathrm{m}^{-3}\right)$ & 1.6 & 7.1 & 5.0 & 1.4 & 8.0 & 16 & 30 & 23 & 10 & 2.8 & 29 & 13 & 5.9 & 25 & 52 & 40 & 14 \\
\hline $\mathrm{EC}\left(\mu \mathrm{g} \mathrm{m}^{-3}\right)$ & 0.3 & 2.1 & 1.2 & 0.5 & 1.0 & 0.0 & 1.1 & 0.6 & 0.8 & 0.7 & 11 & 2.8 & 2.1 & 0.0 & 0.0 & 0.0 & 0.0 \\
\hline
\end{tabular}

to abrasion with wind and/or directly released into the air from incomplete combustion of biomass (Simoneit, 1984; Simoneit et al., 2004c). These $n$-alkanes are of an odd-toeven number carbon preference, which is usually characterized by a carbon preference index (CPI) more than 5. Fossil fuel incomplete combustion is another major source of atmospheric n-alkanes, which are often dominant in urban and industry areas. Fossil fuel derived $n$-alkanes do not have carbon number preference, i.e. CPI is close to unity (Simoneit, 1984; Simoneit et al., 2004c). As shown in Table 1, CPI of total $n$-alkanes is $3.3 \pm 1.1$ and $3.0 \pm 1.7$ at Mt. Hua and Mt. Tai in the NDS time, which means the Mt. Hua aerosols are more influence by plant emissions. During the DS II period, $n$-alkanes were $602 \times 234 \mathrm{ng} \mathrm{m}^{-3}$ at Mt. Hua and $477 \pm 148$ ng m-3 at Mt. Tai, being $2 \pm 3$ times more than those during NDS with CPI of $5.0 \pm 3.5$ and $6.2 \pm 0.7$ at both sites (Ta- ble 1). When dust storm occurred $n$-alkanes showed a sharp increase for odd carbon number of high molecular weight (HMW) $n$-alkanes $\left(>\mathrm{C}_{27}\right)$ with no significant changes for low molecular weight (LMW) $n$-alkanes (Fig. 4b). Such changes in molecular composition indicate organic aerosols during the event are mostly originated from plants in Gobi regions (Fu et al., 2012).

Fatty acids presented a similar composition at the two sites in the NDS time, which is characterized by predominant $\mathrm{C}_{16: 0}$ and $\mathrm{C}_{18: 0}$ with CPI (even-to-odd) of $4.0 \pm 0.7$ and $4.9 \pm 1.3$ at Mt. Hua and Mt. Tai, respectively (Fig. 4c). Fatty acids derived from plant emission are dominated by $\mathrm{C}_{16: 0}, \mathrm{C}_{18: 0}$ and other HMW species with even-number carbon atoms like $\mathrm{C}_{24: 0}, \mathrm{C}_{26: 0}, \mathrm{C}_{28: 0}$, and $\mathrm{C}_{30: 0}$ (Fu et al., 2008b, 2010). Human cooking activity is another important source of fatty acids $\mathrm{C}_{16: 0}, \mathrm{C}_{18: 0}$ and $\mathrm{C}_{18: 1}$ (Schauer et al., 1996; 

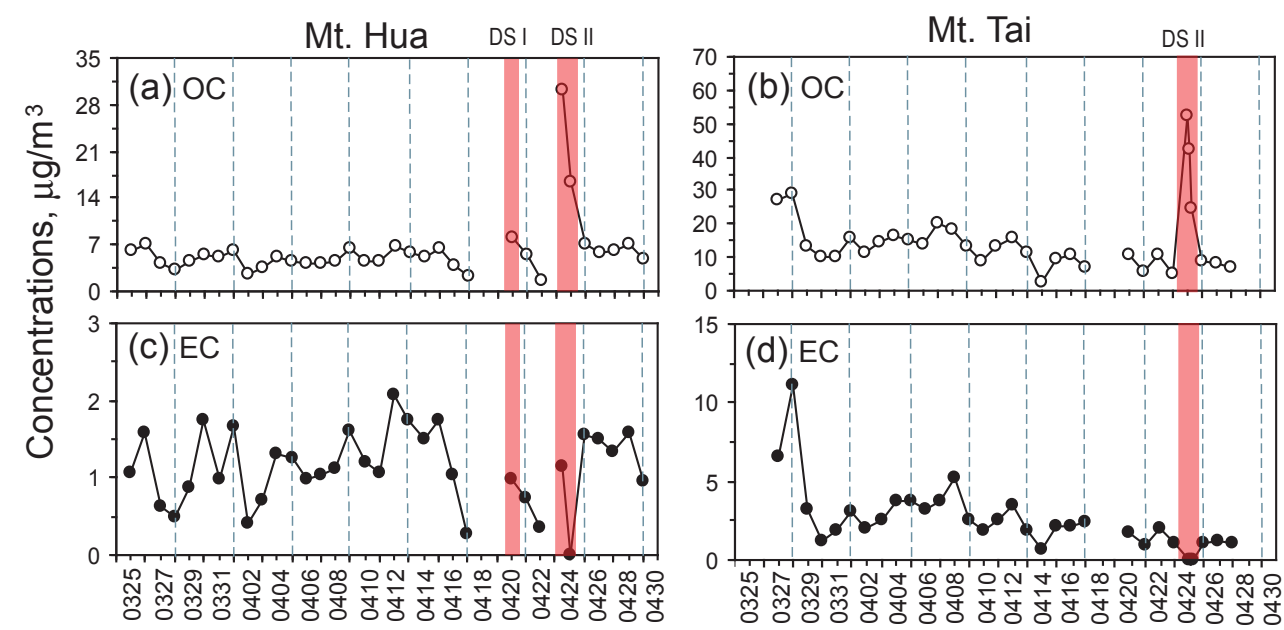

Sampling date in spring 2009

Fig. 3. Temporal variations of $\mathrm{OC}$ and $\mathrm{EC}$ in the $\mathrm{PM}_{10}$ samples collected at Mt. Hua and Mt. Tai during the spring of 2009 (DS I and DS II: dust events).
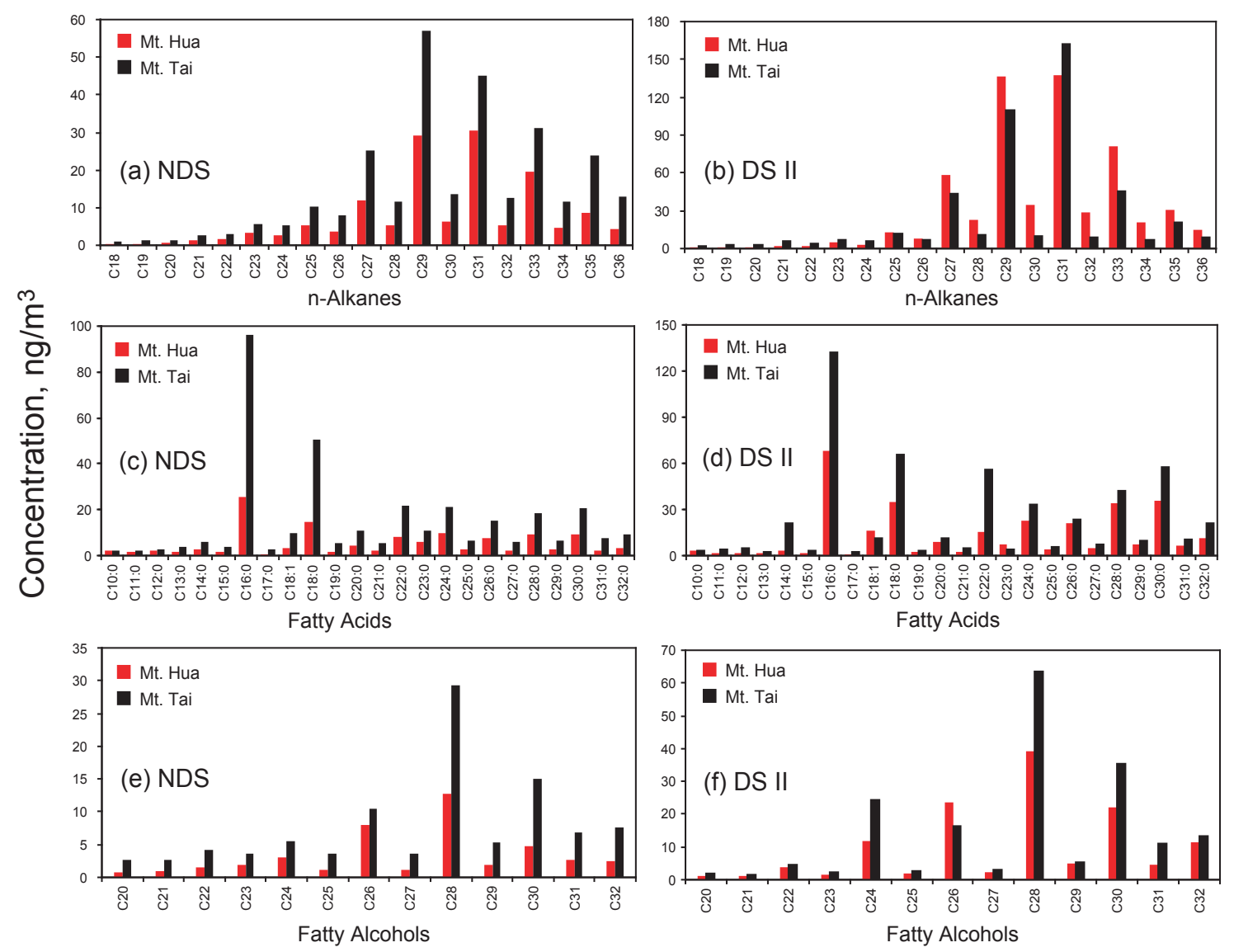

Fig. 4. Differences in molecular composition of $n$-alkanes, fatty acids and fatty alcohols in the $\mathrm{PM}_{10}$ samples at Mt. Hua and Mt. Tai during the non-dust storm (NDS) and the dust storm II (DS II, 24 April 2009) periods. 
Table 2. Diagnostic ratio of PAHs in the $\mathrm{PM}_{10}$ collected at Mt. Hua and Mt. Tai.

\begin{tabular}{|c|c|c|c|c|c|c|c|c|}
\hline & \multicolumn{3}{|c|}{ Mt. Hua } & \multicolumn{2}{|c|}{ Mt. Tai } & \multicolumn{3}{|c|}{ Sources } \\
\hline & NDS & DS I & DS II & NDS & DSII & Gasoline & Diesel & Coal \\
\hline IP/BghiP & $2.2 \pm 0.9$ & 1.9 & $1.4 \pm 0.3$ & $2.1 \pm 0.3$ & $1.1 \pm 0.6$ & $0.22^{\mathrm{a}}$ & $0.50^{\mathrm{a}}$ & $1.3^{\mathrm{a}}$ \\
\hline BghiP/BeP & $0.51 \pm 0.06$ & 0.48 & $0.51 \pm 0.16$ & $0.50 \pm 0.16$ & $0.36 \pm 0.05$ & $2.0^{\mathrm{b}}$ & & $0.8^{\mathrm{c}}$ \\
\hline
\end{tabular}

a Data including noncatalyst and catalyst vehicles and cited from (Grimmer et al., 1983).

${ }^{\mathrm{b}}$ Data including gasoline and diesel and cited from (Ohura et al., 2004).

${ }^{\mathrm{c}}$ Data cited from Ohura et al. (2004).

Simoneit, 1984; Simoneit et al., 2004c). Compared to those in the NDS time HMW fatty acids in the DS II samples significantly increased (Fig. 4d), again suggesting plants in Gobi desert as an important source of organic aerosols. Fatty alcohols are also mainly derived from plant emissions and characterized by an even-number carbon preference. Similar to fatty acids concentrations of HMW fatty alcohols with evennumber carbon atoms sharply enhanced during the dust event (Fig. $4 \mathrm{e}$ and f).

\subsubsection{PAHs and sugars}

PAHs are produced during the incomplete combustion process of carbon-containing materials (Seinfeld and Pandis, 1998). Total PAHs at Mt. Tai during the non-dust storm periods are $23 \pm 19 \mathrm{ng} \mathrm{m}^{-3}$, being 4 times more than those at Mt. Hua, further indicating that North China Plain (NCP) including Mt. Tai is more polluted. Mass ratio of indeno(1,2,3cd)pyrene/ benzo(ghi)perylene (IP/BghiP) is $0.22,0.5$ and 1.3 in the particles emitted from gasoline and diesel vehicle exhaust and coal combustion, respectively, while the mass ratio of benzo(ghi)perylene/benzo(e)pyrene (BghiP/BeP) is separately 2.0 and 0.8 in vehicle exhaust and coal-burning smoke. As shown in Table 2, IP/BghP and BghiP/BeP at two sites during the whole campaign were more close to the ratios of PAHs in coal-burning smoke, which is in agreement with previous studies at Mt. Tai (Wang et al., 2009a) and other Chinese urban areas (Feng et al., 2006; Wang and Kawamura, 2005; Wang et al., 2006, 2007; Xie et al., 2009), confirming that coal combustion, specifically domestic cooking and heating, is still the major source of PAHs in the country, although vehicle exhaust has been sharply increasing. As seen in Table 1, concentrations of LMW PAHs (3,4-ring) in the mountain air was comparable and even higher than those of HMW PAHs (5,6-ring) during the whole sampling period with the concentration ratio of 3,4-ring/5,6-ring being $0.8-1.8$, which is opposite to the cases in urban areas, where HMW PAHs in aerosol phase is generally more abundant than the LMW ones. For example, 3,4-ring /5,6-ring PAHs ratios in Baoji, a city nearby Mt. Hua, was less than 0.5 during spring (Wang et al., 2009b; Xie et al., 2009). The more LMW PAHs in the mountain particles can be ascribed to the lower temperature of the mountain atmosphere, which is favorable for volatile LMW PAHs partitioning into aerosol
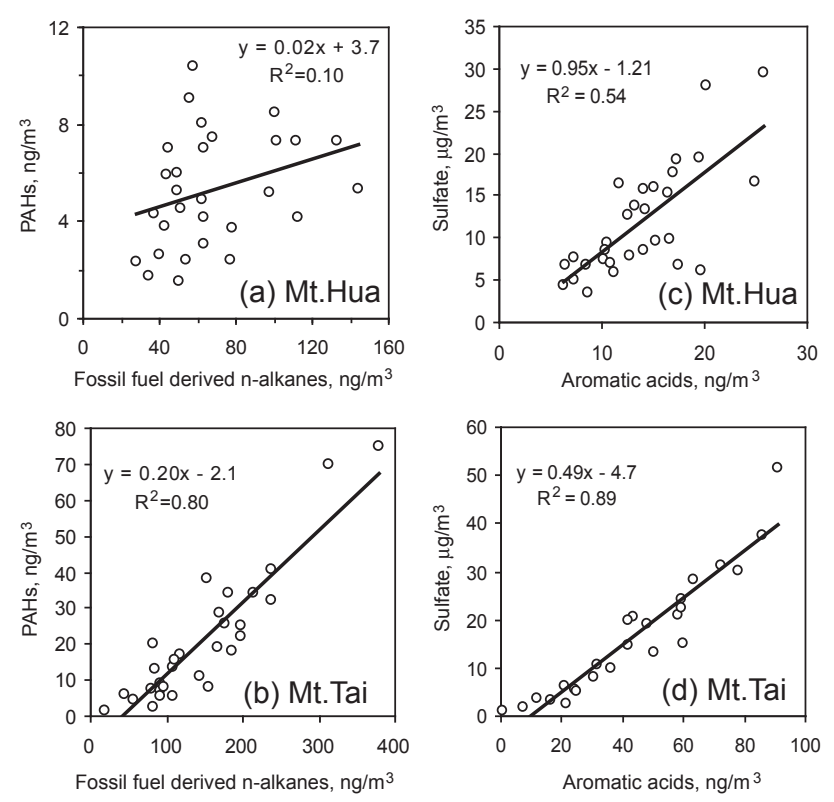

Fig. 5. Linear fit regression for fossil fuel-derived $n$-alkanes with PAHs and aromatic acids with sulfate in the $\mathrm{PM}_{10}$ samples at Mt. Hua and Mt. Tai during the non-dust storm period (samples collected in rainy days were excluded).

phase. A robust linear correlation was found for PAHs and fossil fuel derived $n$-alkanes at Mt. Tai during the nonevent period, but such a correlation was not observed at Mt. Hua (Fig. 5a, b).

Sugars, except for anhydrosaccharides such as galactosan, mannosan and levoglucosan, are metabolism products of biota in soil and pollen (Simoneit et al., 2004b). Dehydrated sugars are pyrolysis products of materials containing cellulose, thus levoglusoan is often considered a key tracer for biomass burning smoke (Simoneit et al., 1999). Levoglucosan during the nonevent time was $48 \pm 20 \mathrm{ng} \mathrm{m}^{-3}$ at Mt. Hua and $158 \pm 95 \mathrm{ng} \mathrm{m}^{-3}$ at Mt. Tai (Table 1 and Fig. 6a, b), which is consistent with a higher level of $\mathrm{K}^{+}$observed at Mt. Tai by our previous measurement $\left(0.4 \pm 0.2 \mu \mathrm{g} \mathrm{m}^{-3}\right.$ at Mt. Hua versus $1.4 \pm 0.8 \mu \mathrm{g} \mathrm{m}^{-3}$ at Mt. Tai) (Wang et al., 2011c), suggesting a more significant biomass burning in NCP. Sucrose is a plant photosynthate accumulated in the 

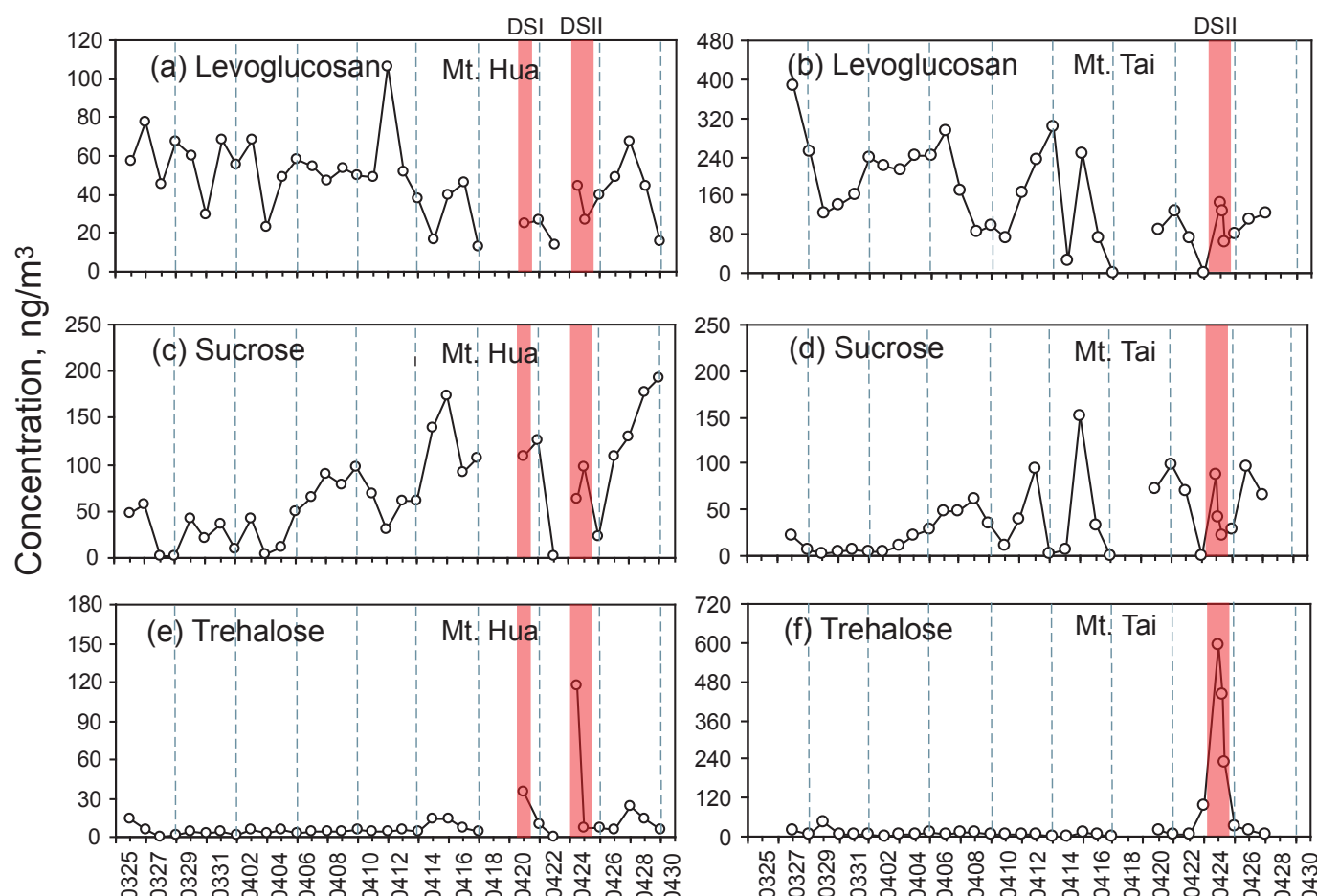

Sampling date in spring 2009

Fig. 6. Temporal variations of sugars in the $\mathrm{PM}_{10}$ samples at Mt. Hua and Mt. Tai during the spring of 2009.

root (Jaeger III et al., 1999), thus its concentration increased from March to April at both sites as temperature increase (Fig. 6c, d). Trehalose is a non-reducing disaccharide of glucose that plays an important physiological role in the stabilization of biological structures in a large number of organisms, including bacteria, yeast, and invertebrates under drought, salinity and low-temperature stresses (Garg et al., 2002). Most plants do not accumulate detectable amounts of trehalose with the exception of the highly desiccationtolerant species (Garg et al., 2002). Thus, trehalose is expected to abundantly exist in dusts of Gobi deserts rather than in soil of the downwind regions. Trehalose showed a very low concentration at both sites during the nonevent, but sharply increased when dust storm presented (Fig. 6e and f). Trehalose during the DS II was $62 \pm 78 \mathrm{ng} \mathrm{m}^{-3}$ at Mt. Hua and $421 \pm 181 \mathrm{ng} \mathrm{m}^{-3}$ at Mt. Tai, being 10 and 30 times more than that during the NDS period, respectively. $\mathrm{Ca}$ and $\mathrm{Ca}^{2+}$ are usually taken as a tracer for dust storm episodes (Sun et al., 2010; Wang et al., 2007, 2010). However, it is difficult to distinguish dust storm-derived $\mathrm{Ca}$ and $\mathrm{Ca}^{2+}$ from local dust. Therefore, source apportionment using $\mathrm{Ca}$ and $\mathrm{Ca}^{2+}$ to recognize the impact of dust storm is in some cases not successful. Trehalose exits abundantly only in dry conditions like deserts and sandy lands in Gobi, thus it is potentially a tracer for dust emissions from Gobi regions.

Table 3 shows the results of principal component analysis (PCA) for sugars in the two mountain atmospheres.
As for Mt. Hua component 1 shows high loadings with all the primary sugars and a weak loading with trehalose, suggesting that component 1 represents biogenic sources including pollen and biota in soil; while component 2 represents biomass burning source for the Mt. Hua samples as it highly correlates with anhydrosugar galactosan and levogucosan (Table 3). Both components account for $69 \%$ of the total variance. As for sugars in the Mt. Tai samples four components were identified (see Table 3). Component 1 represents biomass burning emissions as it shows a high loading with galactosan, mannosan and levoglucosan. Fructose, glucose, and sucrose are mostly derived from pollen, thus component 2 represents plant emissions. Component 3 represents longrange transported dust from desert regions, because it shows a high loading with trehalose as it only abundantly exists in drought. Mannitol is produced largely by biota in soil such as fungi, spores and bacteria (Bauer et al., 2008), thus component 4 represents a local dust emission since it shows a high loading with mannitol. The four components account for $88 \%$ of the total sugars at Mt. Tai. Based on the above PCA analysis, it can be concluded that biomass burning is much more significant at Mt. Tai since it contributes $39 \%$ of the sugars at the east mountain while it contributes only $19 \%$ of the sugars at Mt. Hua (Table 3). 
Table 3. Principal component analysis for sugars in $\mathrm{PM}_{10}$ collected at Mt. Hua and Mt. Tai during spring 2009.

\begin{tabular}{lrrrrrrr}
\hline & \multicolumn{2}{c}{ Mt. Hua $(n=34)$} & & \multicolumn{3}{c}{ Mt.Tai $(n=32)$} \\
\cline { 2 - 3 } \cline { 6 - 7 } & Component 1 & Component 2 & & Component 1 & Component 2 & Component 3 & Component 4 \\
\hline Galactosan & 0.10 & $\mathbf{0 . 9 4}$ & $\mathbf{0 . 9 6}$ & 0.03 & 0.07 & 0.08 \\
Mannosan & -0.15 & 0.31 & & $\mathbf{0 . 9 7}$ & 0.15 & 0.09 & -0.11 \\
Levoglucosan & -0.07 & $\mathbf{0 . 8 8}$ & & $\mathbf{0 . 9 4}$ & 0.06 & -0.22 & -0.02 \\
Fructose & $\mathbf{0 . 9 4}$ & -0.06 & -0.20 & $\mathbf{0 . 9 2}$ & 0.07 & 0.07 \\
Glucose & $\mathbf{0 . 9 1}$ & -0.24 & 0.07 & $\mathbf{0 . 7 3}$ & 0.40 & $\mathbf{0 . 5 3}$ \\
Arabitol & $\mathbf{0 . 9 3}$ & 0.02 & & 0.32 & 0.53 & $-\mathbf{0 . 5 3}$ & 0.05 \\
Mannitol & $\mathbf{0 . 9 3}$ & 0.03 & & -0.02 & -0.20 & -0.04 & $\mathbf{0 . 9 7}$ \\
Inositol & $\mathbf{0 . 8 4}$ & -0.10 & & $\mathbf{0 . 6 0}$ & $\mathbf{0 . 6 9}$ & -0.10 & 0.22 \\
Sucrose & $\mathbf{0 . 7 6}$ & -0.41 & & 0.04 & $\mathbf{0 . 8 0}$ & 0.11 & -0.26 \\
Trehalose & 0.23 & -0.04 & & 0.04 & 0.11 & $\mathbf{0 . 9 4}$ & 0.05 \\
\% of Variance & 50 & 19 & 39 & 23 & 14 & 12 \\
\hline
\end{tabular}

Note: absolute value larger than 0.5 is highlighted in bold.

\subsubsection{Aromatic and dicarboxylic acids}

Aromatic acids in $\mathrm{PM}_{10}$ were $14 \pm 5.3 \mathrm{ng} \mathrm{m}^{-3}$ at Mt. Hua and $49 \pm 5.3 \mathrm{ng} \mathrm{m}^{-3}$ at Mt. Tai in the nonevent time. Atmospheric aromatic acids are mostly produced from photodegradation of fossil fuel derived precursors such as PAHs (Ho et al., 2007; Kawamura and Yasui, 2005) and/or from combustion process of plastic wastes (Jung et al., 2011). Thus the higher concentrations of aromatic acids in the Mt. Tai air further suggest that North China Plain is more polluted by industrial activities. Aromatic acids at both sites were more abundant in the nonevent time than in the event time (Table 1), indicating that the pollutants in the mountain atmospheres are largely derived from local/regional sources instead of long-range transport. Similar to aromatic acids, dicarboxylic acids in the samples also showed much higher concentrations in the NDS time than in the DS time at both sites, again suggesting these compounds are also mostly derived from local/regional sources. Previous studies (Rohrl and Lammel, 2000; Wang et al., 2009c, 2011a) found that succinic acid is largely derived from photo-oxidation of precursors from fossil fuel combustion while malic acid is mostly derived from biomass burning emissions. During the nonevent succinic and malic acids were $24 \pm 15$ and $5.7 \pm 4.5 \mathrm{ng} \mathrm{m}^{-3}$ at Mt. Tai, respectively, 2-4 times higher than those at Mt. Hua (Table 1), probably suggesting that biofuel- and fossil fuel-derived organics in the free troposphere are more abundant in NCP than in central China. As shown in Fig. 5c, d, sulfate in the $\mathrm{PM}_{10}$ samples well correlated with aromatic acids at both sites during the NDS period, which probably not only indicate that sulfate and aromatic acids are originated from similar formation pathways (e.g. an in-cloud formation) (Warneck, 2003) but also suggest that sulfuric acid may promote the SOA formation (Kourtchev et al., 2009; Zhang et al., 2004).

\subsubsection{Backward trajectory analysis}

To further identify the sources of organic aerosols in the two mountain atmospheres, backward trajectory of 72-h air mass was investigated during the spring campaign. During the non-dust event air masses at both sites largely transported from the north and south directions (Fig. 7a, b), while the air masses during the dust storm periods originated from the north only (Fig. 7c, d). Therefore, samples collected during the nonevent can be classified as two groups, i.e. northerly and southerly. As seen in Fig. 8a, b, PAHs at both mountaintops are higher from the northerly than from the southerly with north/south (N/S) ratios of 1.1 at Mt. Hua and 1.3 at Mt. Tai, suggesting coal-burning emissions are more significant in north China. However, compared to those from the southerly aromatic acids and diacids from the northerly were found to be 10-20\% lower at Mt. Hua and 20-30\% lower at Mt. Tai, suggesting that SOA formation in south China is more significant, which is in line with a previous study on aerosols from fourteen Chinese cities (Wang et al., 2006), and mainly due to favorable conditions for SOA formation in the south, i.e. higher temperature and humidity.

\subsection{Size distribution}

The impact of dust on the particle size distribution is very poorly constrained, but potentially important for climate, because the dust particles have indirect effects on the existing aerosol size distribution (Manktelow et al., 2010; Sullivan et al., 2009). A number of studies have observed that when dust occurred sulfate and nitrate was redistributed to larger particles (Mcnaughton et al., 2009; Sullivan et al., 2007; Wang et al., 2011c). However, the impact of the dust on the size distribution of organic aerosols has sparsely characterized (Zamora et al., 2011). To our best knowledge, the current study is the first time to investigate the changes of size distribution of organic aerosols on a molecular level when dust 

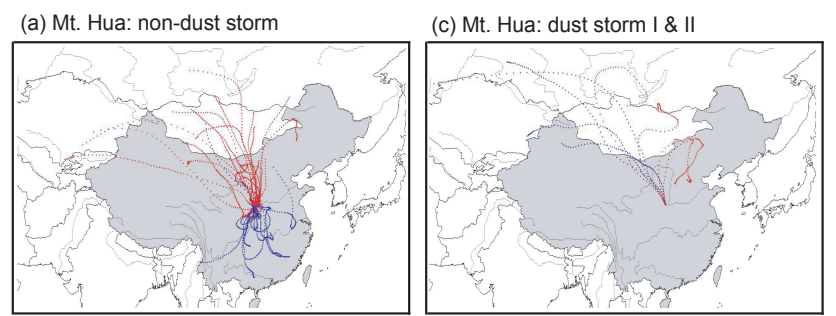

(b) Mt. Tai: non-dust storm

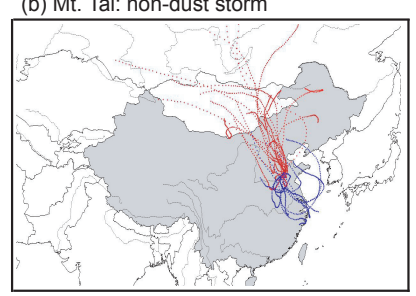

(d) Mt. Tai: dust storm II

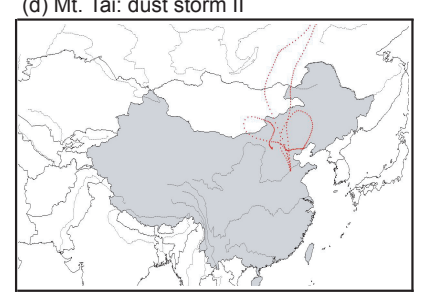

Fig. 7. 72-h Backward trajectories of air masses arriving in Mt. Hua and Mt. Tai during the non-dust storm and the dust storm periods (Blue trajectories in (c) represent DS I while the red ones represent DS II).

storm was occurring. Here we re-group the target compounds in the $\mathrm{PM}_{10}$ samples above to water-insoluble ( $n$-alkanes, fatty acids and PAHs) and -soluble (sugars, aromatic acids and dicarboxylic acids) species and compare their size distribution in the nonevent time with those in the DS II period.

\subsubsection{Water-insoluble organic aerosols}

n-Alkanes (i.e. $\mathrm{C}_{23}$ and $\mathrm{C}_{29}$ ) (Fig. $9 \mathrm{a}-\mathrm{d}$ ) and fatty acids (i.e. $\mathrm{C}_{18: 0}$ and $\mathrm{C}_{30: 0}$ ) (Fig. 9e-h) showed a bimodal size distribution at Mt. Hua and Mt. Tai during the NDS period, maximizing at $0.7-1.1 \mu \mathrm{m}$ and $>3.3 \mu \mathrm{m}$, respectively. However, the coarse mode at Mt. Hua is larger than that at Mt. Tai, which can be explained by more dust in the atmosphere over Guanzhong Plain including Mt. Hua due to its proximity to the Loess Plateau and desert regions in the northwest China. During the DS II period LMW $n$-alkanes (e.g. $\mathrm{C}_{23}$ ) and fatty acids $\left(\mathrm{C}_{18: 1}\right)$ decreased in fine mode and increased in coarse mode, although both still presented as a bimodal pattern (Fig. 9o, q). In contrast, HMW $n$-alkanes (e.g. $\mathrm{C}_{31}$ ) and fatty acids (e.g. $\mathrm{C}_{30: 0}$ ) during the dust event presented as a unimodal pattern, i.e. coarse mode (Fig. 9p, r). Unlike LWM $n$-alkanes and fatty acids, which are in part emitted from anthropogenic sources such as fossil fuel combustion and cooking activity, HMW $n$-alkanes and fatty acids during the DS II were almost entirely derived from dust, thus both concentrated in coarse mode with the size distribution pattern same as dust itself (Wang et al., 2011c).

PAHs are emitted as molecular clusters from the flame region during combustion process and subsequently condense on pre-existing particles when temperature is cool down, thus they stay in fine particles (Seinfeld and Pandis, 1998). Since LMW PAHs are volatile, they can evaporate from fine par-

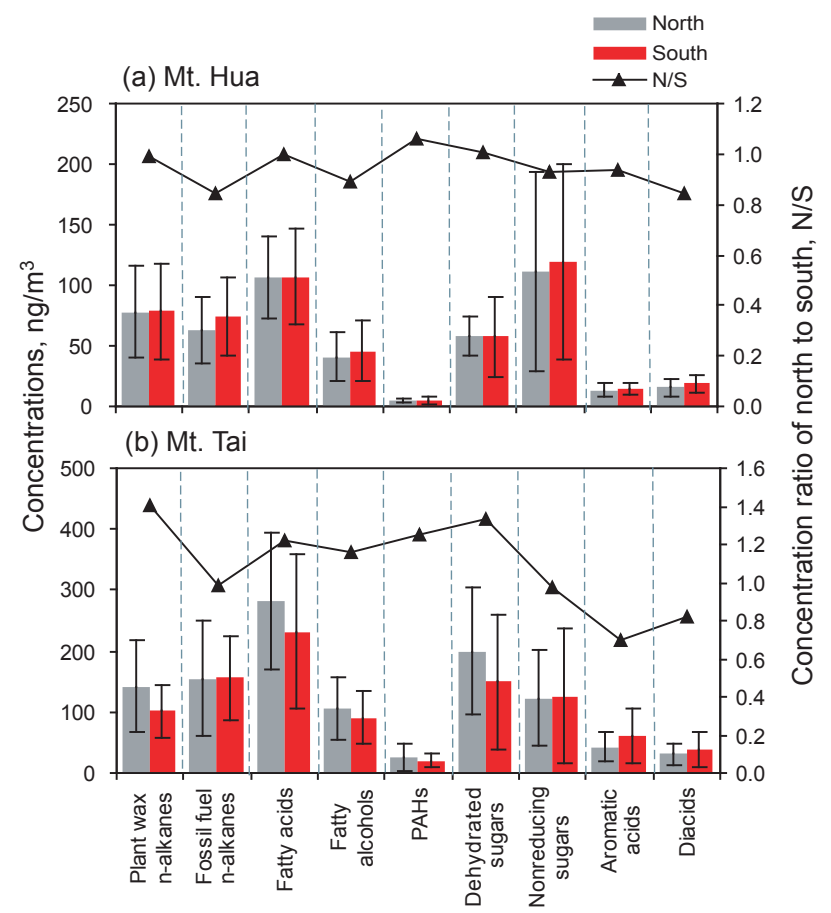

Fig. 8. Comparison of organic aerosols in $\mathrm{PM}_{10}$ from the southerly air masses with those from the northerly air masses at Mt. Hua and Mt. Tai during the non-dust storm period.

ticles and re-adsorb/-condense onto coarse particles (Offenberg and Baker, 1999), thus LMW PAHs showed a bimodal pattern in the NDS time at both sites (Fig. 9i, j). On contrast, HMW PAHs, i.e. fluoranthene (Flu) and benzo(e)pyrene $(\mathrm{BeP})$ were characterized by an accumulation mode during the whole sampling campaign, peaking at $0.7-1.1 \mu \mathrm{m}$ in the mountain atmospheres, due to their lower-/non-volatile nature (Fig. 9k-n and t-u). LMW PAH phenanthrene (Phe) almost evenly distributed in all the size range when dust was present (Fig. 9s). However, on the current stage we cannot give a clear explanation.

\subsubsection{Water-soluble organic aerosols}

Levoglucosan shows a unimodal size distribution at Mt. Hua during the nonevent and the event periods, peaking at the size of $0.7-1.1 \mu \mathrm{m}$, in contrast to a distinct bimodal pattern in fine and coarse modes at Mt. Tai during the NDS periods (Fig. 10a, b and o). The fine mode of levoglucosan is produced from biomass burning process, while levoglucosan in the coarse mode may be derived from coagulation of the fine mode with coarse particles (Herner et al., 2006; Hinds, 1999). Levoglucosan can be activated as cloud condensation nuclei $(\mathrm{CCN})$ under high relative humidity (RH) and further absorb water vapor to grow as fog droplets (Chan et al., 2005; Engling et al., 2009; Mochida and Kawamura, 2004), which are of a diameter larger than $4 \mu \mathrm{m}$ (Seinfeld and 


\section{(I) Non-Dust Storm Period}

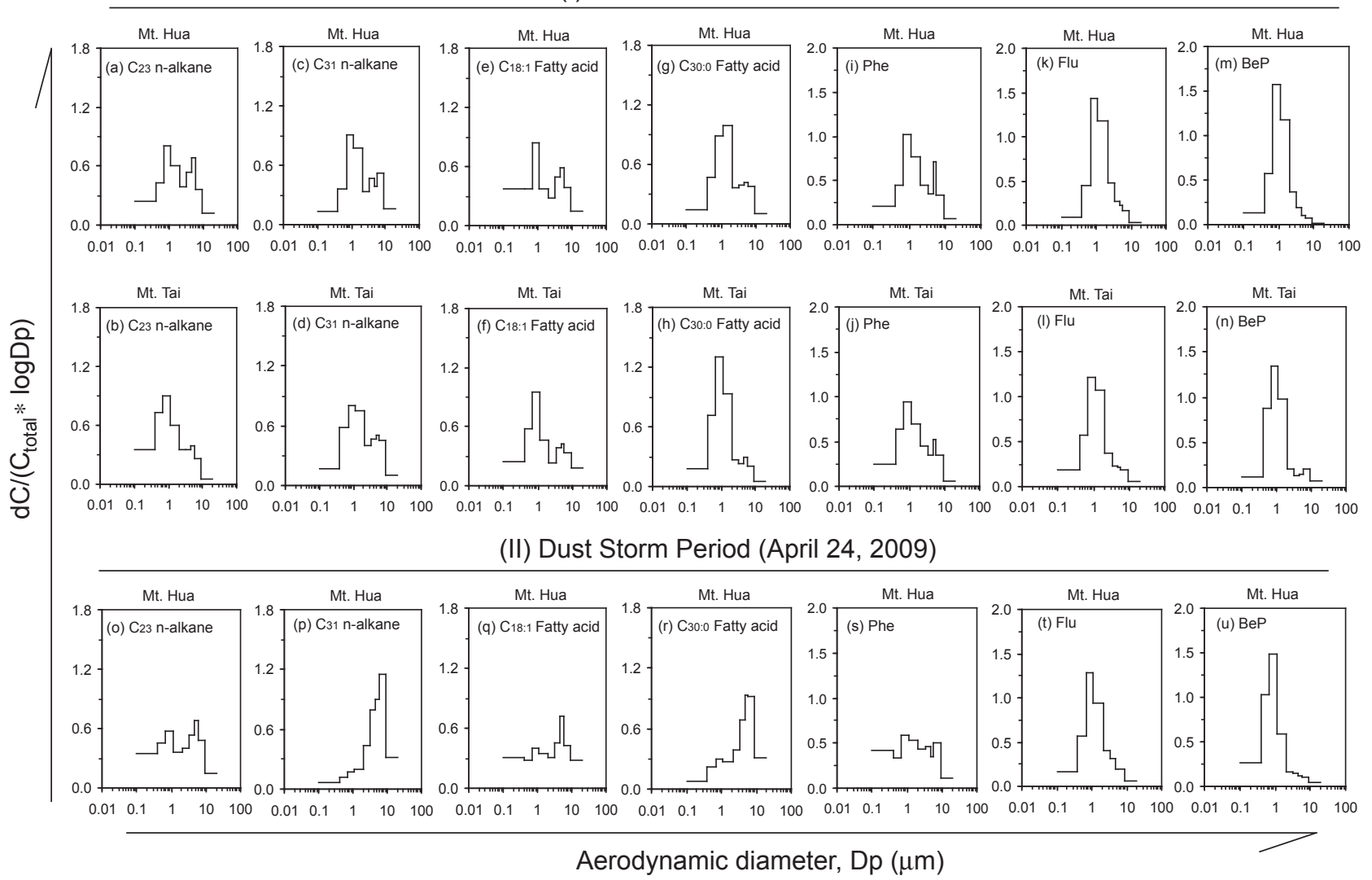

Fig. 9. Differences in size distributions of water-insoluble organic aerosols at Mt. Hua and Mt. Tai during (I) the nonevent and (II) the event periods.

Pandis, 1998). Cloud/fog more frequently occurred at Mt. Tai during the sampling campaign due to its proximity to East China Sea. Thus the water droplets containing levoglucosan might be collected, which is another reason resulting in the coarse mode of levoglucosan at Mt. Tai (Fig. 10b). Glucose mostly originates from pollen, and is thus enriched in coarse mode, although a small amount exists in fine mode in part due to incomplete combustion of cellulose materials (Pio et al., 2006; Wang et al., 2011a) (Fig. 10c, d and p). As discussed above trehalose is mostly derived from biota in desert regions, therefore, only a coarse mode was observed at both sites in the whole sampling time (Fig. 10e, $f$ and q).

Naphthalene is a major precursor of phthalic acid $(\mathrm{Ph})$, which mostly exists in gas phase and can be photochemically oxidized into $\mathrm{Ph}$ followed by a subsequent condensation/adsorption onto pre-existing particles (Agarwal et al., 2010), thus the fine and coarse modes were observed at the two sites during the whole campaign (Fig. 10g, h and r). Two peaks presented in the coarse mode at Mt. Tai in the NDS time (Fig. 10h), which may suggest additional sources of $\mathrm{Ph}$ in the mountain region. Being different from $\mathrm{Ph}$ terephthalic acid (t-Ph) is mostly emitted from combustion process of plastic wastes by a pyrolysis reaction as fine particles, thus predominant in fine mode (Fig. 10i, $\mathrm{j}$ and $\mathrm{s}$ ). The coarse mode of $\mathrm{t}-\mathrm{Ph}$ is possible resulted from a coagulation of the fine mode with coarse particles especially in the DS II time (Fig. $10 \mathrm{j}$ and s). In our previous study (Wang et al., 2011a) we found that succinic acid is much more abundant in urban areas than in rural regions, and secondarily produced from photooxidation of fossil fuel pollutants. Our recent study (Wang et al., 2012) further suggest that 4-oxobutanoic acid, a key intermediate of succinic acid, is originated from photochemical oxidation of gaseous pollutants from fossil fuel combustion, which subsequently partitions into solid phase and further be oxidized into succinic acid. Thus, a dominant peak in the fine mode and a minor peak in the coarse mode were observed at Mt. Hua and Mt. Tai in both the non-dust and the dust periods (Fig. 10k, 1, and t). Compared to succinic acid malic acid in the biomass burning derived aerosols is much more abundant, which was found to be produced directly from combustion process (Wang et al., 2009c, 2011b), thus in generally presented a unimodal at the two mountaintops, peaking at $0.7-1.1 \mu \mathrm{m}(\mathrm{Fig} .10 \mathrm{~m}, \mathrm{n}$ and $\mathrm{u}$ ). 
Table 4. Geometric mean diameters (GMD, $\mu \mathrm{m})^{\mathrm{a}}$ of organic aerosols at Mt. Hua and Mt. Tai during the spring of 2009.

\begin{tabular}{|c|c|c|c|c|c|c|c|c|c|c|c|c|}
\hline & \multicolumn{6}{|c|}{ Mt. Hua } & \multirow{2}{*}{\multicolumn{3}{|c|}{$\frac{\text { Mt. Tai }}{\text { ust storm period }(N=5)}$}} & \multirow{2}{*}{\multicolumn{3}{|c|}{$\begin{array}{c}\text { Mt. Hua/Mt. Tai } \\
\text { Non-dust storm period }\end{array}$}} \\
\hline & \multicolumn{3}{|c|}{ Non-dust storm period $(N=4)$} & \multicolumn{3}{|c|}{ DS II (April 24) $(N=1)$} & & & & & & \\
\hline & Fine & Coarse & Total & Fine & Coarse & Total & Fine & Coarse & Total & Fine & Coarse & Total \\
\hline $\mathrm{PM}$ & $0.81 \pm 0.08$ & $7.14 \pm 0.37$ & $2.84 \pm 0.14$ & 1.05 & 7.23 & 5.79 & $0.79 \pm 0.05$ & $6.95 \pm 0.62$ & $2.44 \pm 0.33$ & 1.02 & 1.03 & 1.16 \\
\hline Plant wax $n$-alkanes & $0.88 \pm 0.06$ & $7.70 \pm 0.57$ & $2.50 \pm 0.53$ & 0.80 & 8.32 & 6.07 & $0.84 \pm 0.06$ & $6.58 \pm 0.62$ & $2.10 \pm 0.47$ & 1.04 & 1.17 & 1.19 \\
\hline Fossil fuel $n$-alkanes & $0.71 \pm 0.13$ & $5.91 \pm 0.09$ & $1.46 \pm 0.51$ & 0.46 & 7.07 & 1.28 & $0.64 \pm 0.10$ & $6.00 \pm 0.91$ & $1.13 \pm 0.15$ & 1.12 & 0.98 & 1.29 \\
\hline Fatty acids & $0.76 \pm 0.01$ & $7.13 \pm 0.48$ & $1.99 \pm 0.29$ & 0.62 & 8.37 & 3.53 & $0.52 \pm 0.10$ & $6.86 \pm 0.39$ & $1.04 \pm 0.42$ & 1.46 & 1.04 & 1.92 \\
\hline 3,4-ring PAHs & $0.89 \pm 0.07$ & $5.44 \pm 0.39$ & $1.43 \pm 0.20$ & 0.71 & 6.37 & 1.37 & $0.81 \pm 0.07$ & $6.28 \pm 0.92$ & $1.44 \pm 0.30$ & 1.10 & 0.87 & 0.99 \\
\hline 5,6-ring PAHs & $0.93 \pm 0.16$ & $5.04 \pm 1.06$ & $1.18 \pm 0.27$ & 0.70 & 7.07 & 1.06 & $0.86 \pm 0.03$ & $7.38 \pm 2.07$ & $1.20 \pm 0.27$ & 1.08 & 0.68 & 0.98 \\
\hline Levoglucosan & $0.79 \pm 0.17$ & $4.47 \pm 0.78$ & $1.22 \pm 0.58$ & 0.74 & 4.38 & 1.09 & $0.61 \pm 0.09$ & $4.90 \pm 0.92$ & $0.88 \pm 0.36$ & 1.30 & 0.91 & 1.38 \\
\hline Glucose & $0.67 \pm 0.14$ & $8.88 \pm 4.05$ & $5.39 \pm 3.41$ & 1.08 & 9.06 & 7.17 & $0.74 \pm 0.08$ & $9.14 \pm 1.89$ & $5.32 \pm 1.63$ & 0.90 & 0.97 & 1.01 \\
\hline Trehalose & $0.76 \pm 0.34$ & $8.46 \pm 3.56$ & $6.37 \pm 1.22$ & 1.40 & 8.04 & 7.45 & $0.80 \pm 0.06$ & $9.62 \pm 1.37$ & $8.52 \pm 1.37$ & 0.94 & 0.88 & 0.75 \\
\hline Phthalic acid & $0.74 \pm 0.06$ & $5.96 \pm 0.76$ & $1.63 \pm 0.37$ & 0.66 & 8.04 & 1.40 & $0.71 \pm 0.01$ & $4.69 \pm 1.19$ & $1.61 \pm 0.44$ & 1.05 & 1.27 & 1.01 \\
\hline Terephthalic acid & $0.91 \pm 0.04$ & $4.65 \pm 0.56$ & $1.38 \pm 0.21$ & 0.71 & 6.33 & 1.12 & $0.70 \pm 0.08$ & $5.00 \pm 1.08$ & $1.22 \pm 0.28$ & 1.31 & 0.93 & 1.13 \\
\hline Succinic acid & $0.81 \pm 0.05$ & $6.47 \pm 0.64$ & $1.83 \pm 0.34$ & 0.74 & 7.74 & 1.80 & $0.85 \pm 0.06$ & $5.35 \pm 1.33$ & $1.54 \pm 0.66$ & 0.96 & 1.21 & 1.19 \\
\hline Malic acid & $0.82 \pm 0.22$ & $5.45 \pm 1.01$ & $1.12 \pm 0.54$ & 0.56 & 8.17 & 0.93 & $0.81 \pm 0.04$ & $5.13 \pm 0.52$ & $1.08 \pm 0.17$ & 1.00 & 1.06 & 1.04 \\
\hline
\end{tabular}

Note: $\operatorname{LogGMD}=\left(\sum C_{i} \log D p_{i}\right) / \sum C_{i}$, where $C_{i}$ is the concentration of compound in size $i$ and $D p_{i}$ is the geometric mean particle diameter collected on stage $i$ (Hinds, 1999).

(I) Non-Dust Storm Period

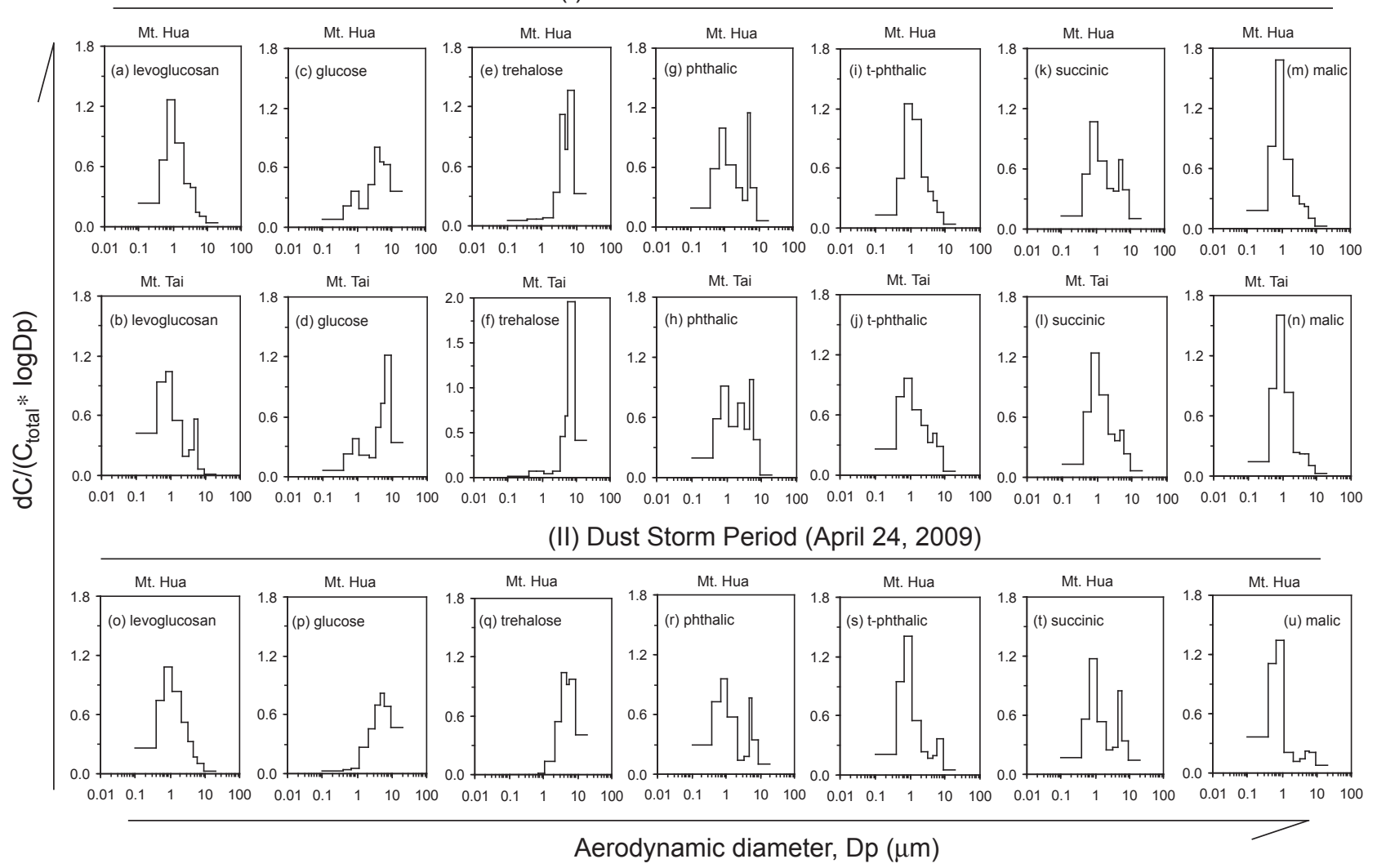

Fig. 10. Differences in size distributions of water-soluble organic aerosols at Mt. Hua and Mt. Tai during (I) the nonevent and (II) the event periods.

\subsubsection{Geometric Mean Diameter (GMD)}

To further recognize the impact of dust storm on the size distribution of the organics, geometric mean diameter (GMD) of the selected species was calculated and shown in Table 4 according to the size ranges of fine $(<2.5 \mu \mathrm{m})$, coarse
$(>2.5 \mu \mathrm{m})$ and the total $(<100 \mu \mathrm{m})$. Compared to those at Mt. Tai GMDs in the whole size range was larger at Mt. Hua except for PAHs, both LMW (3,4-ring) and HMW (5,6-ring) PAHs showed similar GMDs in the whole size range, although PAHs at Mt. Hua showed larger fine mode GMDs and smaller coarse mode GMDs. As seen in Table 4, the total 
GMDs of particles and all the biogenic aerosols (e.g. plant wax derived $n$-alknes, fatty acids, glucose and trehalose) became larger when dust was present. In contrast, the total GMDs of all the anthropogenic aerosols, such as fossil fuel derived $n$-alkanes, PAHs, aromatic acids and diacids, became smaller in the DS II event. We believe that anthropogenic pollutants at Mt. Hua in the nonevent time are mostly originated from local/regional sources rather than from longrange transport, and diluted by the northerly air masses during the dust event. High wind speed in the DS II time made the local/regional organic aerosols being quickly transported onto the mountaintop, and thus their residential time in the air was shorter. As a result, the coagulation effect of these organic aerosols during the event was less efficient. Moreover, particle coagulation is a function of particle concentration (Herner et al., 2006; Hinds, 1999), thus the local organic aerosol coagulation is further decreased when diluted by the northerly air masses. Therefore, the total GMDs of the anthropogenic organic aerosols became smaller during the DS II period.

\section{Summary and conclusion}

$\mathrm{PM}_{10}$ and size-segregated aerosols in the atmospheres over Mt. Hua and Mt. Tai were simultaneously collected during the spring 2009 including a massive dust storm event occurred on 24 April (DS II), and characterized for organic compounds. During the nonevent period $n$-alkanes, fatty acids, fatty alcohols in the $\mathrm{PM}_{10}$ samples at Mt. Tai are $284 \pm 120,344 \pm 150$ and $100 \pm 48 \mathrm{ng} \mathrm{m}^{-3}$, respectively, two times more than those at Mt. Hua, while PAHs $\left(23 \pm 19 \mathrm{ng} \mathrm{m}^{-3}\right)$, levoglucosan $\left(158 \pm 95 \mathrm{ng} \mathrm{m}^{-3}\right)$, aromatic acids $\left(49 \pm 34 \mathrm{ng} \mathrm{m}^{-3}\right)$ and dicarboxylic acids $\left(42 \pm 25 \mathrm{ng} \mathrm{m}^{-3}\right)$ at Mt. Tai are $2-4$ times more than those at Mt. Hua, suggesting that air pollution in the NCP including Mt. Tai is more serious. During the DS II period a sharp increase in HMW $n$-alkanes, fatty acids, and fatty alcohols and trehalose and a significant decrease in aromatic acids and dicarboxylic acid were observed at both sites, indicating that POA during the event are largely derived from biogenic sources in the Gobi desert and SOA are mostly derived from local/regional anthropogenic sources. Trehalose is only abundantly existed in dry condition like Gobi regions and two orders of magnitude higher in the event than in the nonevent. Thus we propose trahalose as a potential tracer for dust emissions from desert areas. Robust linear correlations between sulfate and aromatic acids in the $\mathrm{PM}_{10}$ samples at both sites may suggest a common formation pathway and/or a synergistic effect during formation. Backward trajectory analysis showed an enhanced SOA formation in the southerly than in the northerly due to favorable conditions. Moreover, higher levels of levoglucosan and malic acid in the Mt. Tai air confirmed more significant biomass burning emission in NCP.
$n$-Alkanes and fatty acids showed a bimodal pattern in the nonevent period with large peak in the fine mode and a small peak in the coarse mode. In contrast, during the event LMW $n$-alkanes and fatty acids shifted toward larger size ranges with a dominant peak in the fine mode, although HMW $n$ alkanes and fatty acids during the DS II were dominant in the coarse mode due to a predominant origin from the dust. PAHs at the two sites mostly stayed in the fine mode as a unimodal pattern during both the nonevent and the event periods, except for LMW PAHs, which are volatile and showed a bimodal pattern with a major peak in the fine fraction and a minor peak in the coarse fraction. Anhydrosacchrides (i.e. levoglucosan, galactosan and mannosan) were dominated in fine mode at both sites during the whole campaign, while the non-reducing sugars were enriched in coarse particles especially when dust was present. Phthalic and succinic acids are produced from photo-oxidation of gas-phase precursors, thus both presented a bimodal pattern during the campaign with an increase in coarse mode during the event. Terephthalic and malic acids were dominated as fine mode during the whole campaign with a slight increase in coarse mode when dust was present. GMDs of particles and most organic compounds at Mt. Hua during the nonevent period were larger than those at Mt. Tai due to more dust in the Mt. Hua air. Fossil fuel derived $n$-alkanes, PAHs, levoglucosan, aromatic acids and diacids at Mt. Hua showed a smaller GMD when dust was present, mostly due to a decreased fine particle coagulation caused by a dilution effect. However, plant wax derived $n$-alkanes, fatty acids, glucose, and trehalose were largely transported from Gobi desert in the DS II period, and thus presented a larger GMD.

Acknowledgements. This work was financially supported by China Natural Science Foundation (No. 40873083) and the Knowledge Innovation Program (No. KZCX2-YW-148) and the Strategic Priority Research Program (No. XDA05100103) of Chinese Academy of Sciences.

Edited by: L. Molina

\section{References}

Agarwal, S., Aggarwal, S. G., Okuzawa, K., and Kawamura, K.: Size distributions of dicarboxylic acids, ketoacids, a-dicarbonyls, sugars, WSOC, OC, EC and inorganic ions in atmospheric particles over Northern Japan: implication for long-range transport of Siberian biomass burning and East Asian polluted aerosols, Atmos. Chem. Phys., 10, 5839-5858, doi:10.5194/acp-10-58392010, 2010.

Akimoto, H.: Global air quality and pollution, Science, 302, 17161719, 2003.

Akimoto, $\mathrm{H}$. and Narita, $\mathrm{H}$.: Distribution of $\mathrm{SO}_{2}, \mathrm{NO}_{\mathrm{x}}$ and $\mathrm{CO}_{2}$ emissions from fuel combustion and industrial activities in Asia with 1o X 1o resolution, Atmos. Environ., 28, 213-255, 1994. 
Arimoto, R., Zhang, X. Y., Huebert, B. J., Kang, C. H., Savoie, D. L., Prospero, J. M., Sage, S. K., Schloesslin, C. A., Khaing, H. M., and Oh, S. N.: Chemical composition of atmospheric aerosols from Zhenbeitai, China, and Gosan, South Korea, during ACE-Asia, J. Geophys. Res., 109, D19S04, doi:10.1029/2003JD004323, 2004.

Bauer, H., Claeys, M., Vermeylen, R., Schueller, E., Weinke, G., Berger, A., and Puxbaum, H.: Arabitol and mannitol as tracers for the quantification of airborne fungal spores, Atmos. Environ., 42, 588-593, 2008.

Chan, M. N., Choi, M. Y., Ng, N. L., and Chan, C. K.: Hygroscopicity of water-soluble organic compounds in atmospheric aerosols: Amino acids and biomass burning derived organic species, Environ. Sci. Technol., 39, 1555-1562, 2005.

Decesari, S., Facchini, M. C., Fuzzi, S., Mcfiggans, G. B., Coe, H., and Bower, K. N.: The water-soluble organic component of sizesegregated aerosol, cloud water and wet depositions from Jeju Island during ACE-Asia, Atmos. Environ., 39, 211-222, 2005.

Dunlea, E. J., DeCarlo, P. F., Aiken, A. C., Kimmel, J. R., Peltier, R. E., Weber, R. J., Tomlinson, J., Collins, D. R., Shinozuka, Y., McNaughton, C. S., Howell, S. G., Clarke, A. D., Emmons, L. K., Apel, E. C., Pfister, G. G., van Donkelaar, A., Martin, R. V., Millet, D. B., Heald, C. L., and Jimenez, J. L.: Evolution of Asian aerosols during transpacific transport in INTEX-B, Atmos. Chem. Phys., 9, 7257-7287, doi:10.5194/acp-9-7257-2009, 2009.

Engling, G., Lee, J. J., Tsai, Y. W., Lung, S. C. C., Chou, C. C. K., and Chan, C. Y.: Size-Resolved Anhydrosugar Composition in Smoke Aerosol from Controlled Field Burning of Rice Straw, Aerosol Sci. Technol., 43, 662-672, 2009.

Feng, J. L., Chan, C. K., Fang, M., Hu, M., He, L. Y., and Tang, $\mathrm{X}$. Y.: A comparative study of the organic matter in $\mathrm{PM}_{2.5}$ from three Chinese megacities in three different climatic zones, Atmos. Environ. 40, 3983-3994, 2006.

Fu, J. S., Jang, C. J., Streets, D. G., Li, Z., Kwok, R., Park, R., and Han, Z.: MICS-Asia II: Modeling gaseous pollutants and evaluating an advanced modeling system over East Asia, Atmos. Environ., 42, 3571-3583, 2008a.

Fu, T.-M., Jacob, D. J., Wittrock, F., Burrows, J. P., Vrekoussis, M., and Henze, D. K.: Global budgets of atmospheric glyoxal and methylglyoxal, and implications for formation of secondary organic aerosols, J. Geophys. Res., 113, D15303, doi:15310.11029/12007JD009505, 2008c.

Fu, P., Kawamura, K., Okuzawa, K., Aggarwal, S. G., Wang, G., Kanaya, Y., and Wang, Z.: Molecular characteristics, sources and temporal variations of summertime organic aerosols in the troposphere over Mt. Tai, North China Plain, J. Geophys. Res., 113, D19107, doi:10.1029/2008JD009900, 2008b.

Fu, P. Q., Kawamura, K., Pavuluri, C. M., Swaminathan, T., and Chen, J.: Molecular characterization of urban organic aerosol in tropical India: contributions of primary emissions and secondary photooxidation, Atmos. Chem. Phys., 10, 2663-2689, doi:10.5194/acp-10-2663-2010, 2010.

Fu, P., Kawamura, K., Kobayashi, M., and Simoneit, B. R. T.: Seasonal variations of sugars in atmospheric particulate matter from Gosan, Jeju Island: Significant contributions of airborne pollen and Asian dust in spring, Atmos. Environ., 55, 234-239, 2012.

Garg, A. K., Kim, J.-K., Owens, T. G., Ranwala, A. P., Choi, Y. D., Kochian, L. V., and Wu, R. J.: Trehalose accumulation in rice plants confers high tolerance levels to different abiotic stresses, P. Natl. Acad. Sci. USA, 99, 15898-15903, 2002.

Geng, H., Park, Y., Hwang, H., Kang, S., and Ro, C.-U.: Elevated nitrogen-containing particles observed in Asian dust aerosol samples collected at the marine boundary layer of the Bohai Sea and the Yellow Sea, Atmos. Chem. Phys., 9, 6933-6947, doi:10.5194/acp-9-6933-2009, 2009.

Grimmer, G., Jacob, J., and Noujack, K. W.: Profile of the polycyclic aromatic hydrocarbons from lubricating oils. Inventory by GC/MS-PAH in environmental materials, Part 1, Fresenius Zeitschrift fur Analytishe Chemie, 314, 13-19, 1983.

Herner, J. D., Ying, Q., Aw, J., Gao, O., Chang, D. P. Y., and Kleeman, M. J.: Dominant mechanism that shape the airborne particle size and composition distribution in central California, Aerosol Sci. Technol., 40, 827-844, 2006.

Hinds, W. C.: Aerosol Technology: Properties, Behavior, and Measurement of Airborne Particles, John Wiley \& Sons, New York, 19999.

Ho, K. F., Cao, J. J., Lee, S. C., Kawamura, K., Zhang, R. J., Chow, J. C., and Watson, J. G.: Dicarboxylic acids, ketocarboxylic acids, and dicarbonyls in the urban atmosphere of China, J. Geophys. Res., 112, D22S27, doi:1029/2006JD008011, 2007.

Huang, K., Zhuang, G. S., Li, J. A., Wang, Q. Z., Sun, Y. L., Lin, Y. F., and Fu, J. S.: Mixing of Asian dust with pollution aerosol and the transformation of aerosol components during the dust storm over China in spring 2007, J. Geophys. Res., 115, D00K13, doi:10.1029/2009JD013145, 2010.

Huebert, B. J., Bates, T., Russell, P. B., Shi, G. Y., Kim, Y. J., Kawamura, K., Carmichael, G., and Nakajima, T.: An overview of ACE-Asia: Strategies for quantifying the relationships between Asian aerosols and their climatic impacts, J. Geophys. Res., 108, 8663, doi:8610.1029/2003JD003550, 2003.

IPCC, The Fourth Assessment Report of the Intergovernmental Panel on Climate Change, Cambridge University Press, New York, USA, 2007.

Jaeger III, C. H., Lindow, S. E., Miller, W., Clark, E., and Firestone, M. K.: Mapping of sugar and amino acid availability in soil around roots with bacterial sensors of sucrose and tryptophan, App. Environ. Microb., 65, 2685-2690, 1999.

Kawamura, K. and Yasui, O.: Diurnal changes in the distribution of dicarboxylic acids, ketocarboxylic acids and dicarbonyls in the urban Tokyo atmosphere, Atmos. Environ., 39, 1945-1960, 2005.

Kourtchev, I., Copolovici, L., Claeys, M., and Maenhaut, W.: Characterization of Atmospheric Aerosols at a Forested Site in Central Europe, Environ. Sci. Technol., 43, 4665-4671, 2009.

Leaitch, W. R., Macdonald, A. M., Anlauf, K. G., Liu, P. S. K., Toom-Sauntry, D., Li, S.-M., Liggio, J., Hayden, K., Wasey, M. A., Russell, L. M., Takahama, S., Liu, S., van Donkelaar, A., Duck, T., Martin, R. V., Zhang, Q., Sun, Y., McKendry, I., Shantz, N. C., and Cubison, M.: Evidence for Asian dust effects from aerosol plume measurements during INTEXB 2006 near Whistler, BC, Atmos. Chem. Phys., 9, 3523-3546, doi:10.5194/acp-9-3523-2009, 2009.

Li, J. J., Wang, G. H., Zhou, B. H., Cheng, C. L., Cao, J. J., Shen, Z. X., and An, Z. S.: Chemical composition and size distribution of wintertime aerosols in the atmosphere of Mt. Hua in central China, Atmos. Environ., 45, 1251-1258, 2011. 
Manktelow, P. T., Carslaw, K. S., Mann, G. W., and Spracklen, D. V.: The impact of dust on sulfate aerosol, $\mathrm{CN}$ and $\mathrm{CCN}$ during an East Asian dust storm, Atmos. Chem. Phys., 10, 365-382, doi:10.5194/acp-10-365-2010, 2010.

McNaughton, C. S., Clarke, A. D., Kapustin, V., Shinozuka, Y., Howell, S. G., Anderson, B. E., Winstead, E., Dibb, J., Scheuer, E., Cohen, R. C., Wooldridge, P., Perring, A., Huey, L. G., Kim, S., Jimenez, J. L., Dunlea, E. J., DeCarlo, P. F., Wennberg, P. O., Crounse, J. D., Weinheimer, A. J., and Flocke, F.: Observations of heterogeneous reactions between Asian pollution and mineral dust over the Eastern North Pacific during INTEX-B, Atmos. Chem. Phys., 9, 8283-8308, doi:10.5194/acp-9-8283-2009, 2009.

Mochida, M. and Kawamura, K.: Hygroscopic properties of levoglucosan and related organic compounds characteristic to biomass burning aerosol particles, J. Geophys. Res., 109, D21202, doi:10.1029/2004JD004962, 2004.

Offenberg, J. H. and Baker, J. E.: Aerosol size distributions of polycyclic aromatic hydrocarbons in urban and over-water atmospheres, Environ. Sci. Technol., 33, 3324-3331, 1999.

Ohura, T., Amagai, T., Fusaya, M., and Matsushita, H.: Polycyclic aromatic hydrocarbons in indoor and outdoor environments and factors affecting their concentrations, Environ. Sci. Technol., 38, 77-83, 2004.

Pathak, R. K., Wang, T., and Wu, W. S.: Nighttime enhancement of $\mathrm{PM}_{2.5}$ nitrate in ammonia-poor atmospheric conditions in Beijing and Shanghai: Plausible contributions of heterogeneous hydrolysis of $\mathrm{N}_{2} \mathrm{O}_{5}$ and $\mathrm{HNO}_{3}$ partitioning, Atmos. Environ., 45, 1183-1191, 2010.

Pio, C., Alves, C., Carvalho, A., and Santos, C.: Size distribution characteristics of organic species in atmospheric particulate matter from Finnish and German rural sites with variable anthropogenic influence, Environ. Eng. Sci., 22, 933-941, 2006.

Rohrl, A. and Lammel, G.: Dicarboxylic acids in atmospheric aerosols: Local or regional formation?, J. Aerosol Sci., 31, 348$349,2000$.

Schauer, J. J., Rogge, W. F., Hildemann, L. M., Mazurek, M. A., Cass, G. R., and Simoneit, B. R. T.: Source apportionment of airborne particulate matter using organic compounds as tracers, Atmos. Environ., 30, 3837-3855, 1996.

Seinfeld, J. H. and Pandis, S. N.: Atmospheric Chemistry and Physics, John Wiley \& Sons, New York, 1998.

Seinfeld, J. H., Carmichael, G. R., Arimoto, R., Conant, W. C., Brechtel, F. J., Bates, T. A., Cahill, T. A., Clarke, A. D., Doherty, S. J., Flatau, P. J., Huebert, B. J., Kim, J., Markowicz, K. M., Quinn, P. K., Russell, L. M., Russell, P. B., Shimizu, A., Shinozuka, Y., Song, C. H., Tang, Y. H., Uno, I., Vogelmann, A. M., Weber, R. J., Woo, J. H., and Zhang, X. Y.: ACE-Asia: Regional climatic and atmospheric chemical effects of Asian dust and pollution, B. Am. Meteorol. Soc., 85, 367-380, doi:10.1175/BAMS85-3-367, 2004.

Simoneit, B. R. T.: Application of molecular marker analysis to reconcile sources of carbonaceous particulates in tropospheric aerosols, Sci. Total Environ., 36, 61-72, 1984.

Simoneit, B. R. T., Schauer, J. J., Nolte, C. G., Oros, D. R., Elias, V. O., Fraser, M. P., Rogge, W. F., and Cass, G. R.: Levoglucosan: a tracer for cellulose in biomass burning and atmospheric particles, Atmos. Environ., 33, 173-182, 1999.
Simoneit, B. R. T., Kobayashi, M., Mochida, M., Kawamura, K., and Huebert, B. J.: Aerosol particles collected on aircraft flights over the northwestern Pacific region during the ACE-Asia campaign: Composition and major sources of the organic compounds, J. Geophys. Res., 109, D19S09, doi:10.1029/2004JD004565, 2004a.

Simoneit, B. R. T., Elias, V. O., Kobayashi, M., Kawamura, K., Rushdi, A. I., Medeiros, P. M., Rogge, W. F., and Didyk, B. M.: Sugars - dominant water-soluble organic compounds in soils and characterization as tracers in atmospheric particulate matter, Environ. Sci. Technol., 38, 5939-5949, 2004b.

Simoneit, B. R. T., Kobayashi, M., Mochida, M., Kawamura, K., Lee, M., Lim, H. J., Turpin, B. J., and Komazaki, Y.: Composition and major sources of organic compounds of aerosol particulate matter sampled during the ACE-Asia campaign, J. Geophys. Res.-Atoms, 109, D19S10, doi:10.1029/2004JD004598, 2004c.

Sullivan, R. C., Guazzotti, S. A., Sodeman, D. A., and Prather, K. A.: Direct observations of the atmospheric processing of Asian mineral dust, Atmos. Chem. Phys., 7, 1213-1236, doi:10.5194/acp-7-1213-2007, 2007.

Sullivan, R. C., Moore, M. J. K., Petters, M. D., Kreidenweis, S. M., Roberts, G. C., and Prather, K. A.: Effect of chemical mixing state on the hygroscopicity and cloud nucleation properties of calcium mineral dust particles, Atmos. Chem. Phys., 9, 33033316, doi:10.5194/acp-9-3303-2009, 2009.

Sun, Y., Zhuang, G., Huang, K., Li, J., Wang, Q., Wang, Y., Lin, Y., Fu, J. S., Zhang, W., Tang, A., and Zhao, X: Asian dust over northern China and its impact on the downstream aerosol chemistry in 2004, J. Geophys. Res.-Atmos., 115, D00KO09, doi:10.1029/2009JD012757, 2010.

Tobo, Y., Zhang, D., Matsuki, A., and Iwasaka, Y.: Asian dust particles converted into aqueous droplets under remote marine atmospheric conditions, P. Natl Acad. Sci. USA, 107, 17905-17910, 2010.

Uno, I., Eguchi, K., Yumimoto, K., Takemura, T., Shimizu, A., Uematsu, M., Liu, Z. Y., Wang, Z. F., Hara, Y., and Sugimoto, N.: Asian dust transported one full circuit around the globe, Nat. Geosci., 2, 557-560, 2009.

van Donkelaar, A., Martin, R. V., Brauer, M., Kahn, R., Levy, R., Verduzco, C., and Villeneuve, P. J.: Global estimates of ambient fine particulate matter concentrations from satellite-based aerosol optical depth: development and application, Environ. Health Perspect., 118, 8347-8355, 2010.

Vancuren, R. A. and Cahill, T. A.: Asian aerosols in North America: Frequency and concentration of fine dust, J. Geophys. Res., 107, 4804, doi:10.1029/2002JD002204, 2002.

Wang, G., Kawamura, K., and Lee, M.: Comparison of organic compositions in dust storm and normal aerosol samples collected at Gosan, Jeju Island, during spring 2005, Atmos. Environ., 43, 219-227, 2009a.

Wang, G., Kawamura, K., Xie, M., Hu, S., Gao, S., Cao, J., An, Z., and Wang, Z.: Size-distributions of $n$-alkanes, PAHs and hopanes and their sources in the urban, mountain and marine atmospheres over East Asia, Atmos. Chem. Phys., 9, 8869-8882, doi:10.5194/acp-9-8869-2009, 2009 b.

Wang, G., Kawamura, K., Xie, M., Hu, S., Cao, J., An, Z., Watson, J. G., and Chow, J. C.: Organic molecular compositions and size distributions of Chinese summer and autumn aerosols from Nanjing: Characteristic haze event caused by wheat straw burning, 
Environ. Sci. Technol., 43, 6493-6499, 2009c.

Wang, G., Kawamura, K., Hu, S., Xie, M., Zhou, B., Li, J., Cao, J., and An, Z.: Selected water-soluble organic compounds found in size-resolved aerosols collected from the urban, mountain, and marine atmospheres over East Asia, Tellus B, 63, 371-381, 2011a.

Wang, G., Chen, C., Li, J., Zhou, B., Xie, M., Hu, S., Kawamura, K., and Chen, Y.: Molecular composition and size distribution of sugars, sugar-alcohols and carboxylic acids in airborne particles during a severe urban haze event caused by wheat straw burning, Atmos. Environ., 45, 2473-2479, 2011 b.

Wang, G., Li, J., Cheng, C., Hu, S., Xie, M., Gao, S., Zhou, B., Dai, W., Cao, J., and An, Z.: Observation of atmospheric aerosols at Mt. Hua and Mt. Tai in central and east China during spring 2009 - Part 1: EC, OC and inorganic ions, Atmos. Chem. Phys., 11, 4221-4235, doi:10.5194/acp-11-4221-2011, $2011 \mathrm{c}$.

Wang, G., Kawamura, K., Cao, J., Zhang, R., Cheng, C., Li, J., Zhang, T., Liu, S., and Zhao, Z.: Molecular distribution and stable carbon isotopic composition of dicarboxylic acids, ketocarboxylic acids and $\alpha$-dicarbonyls in size-resolved atmospheric particles from Xi'an city, China, Environ. Sci. Technol., 46, 4783-4791, 2012.

Wang, G. H. and Kawamura, K.: Molecular characteristics of urban organic aerosols from Nanjing: A case study of a mega-city in China, Environ. Sci. Technol., 39, 7430-7438, 2005.

Wang, G. H., Kawamura, K., Lee, S. C., Ho, K. F., and Cao, J. J.: Molecular, seasonal and spatial distributions of organic aerosols from fourteen Chinese cities, Environ. Sci. Technol., 40, 46194625, 2006.

Wang, G. H., Kawamura, K., Zhao, X., Li, Q. G., Dai, Z. X., and Niu, H. Y.: Identification, abundance and seasonal variation of anthropogenic organic aerosols from a mega-city in China, Atmos. Environ., 41, 407-416, 2007a.
Wang, Y., Zhuang, G. S., Tang, A. H., Zhang, W. J., Sun, Y. L., Wang, Z. F., and An, Z. S.: The evolution of chemical components of aerosols at five monitoring sites of China during dust storms, Atmos. Environ., 41, 1091-1106, $2007 \mathrm{~b}$.

Wang, W. J., Cheng, T. T., Zhang, R. J., Jia, X. A., Han, Z. W., Zhang, X. L., Xu, X. F., and Li, D. P.: Insights into an Asian dust event sweeping Beijing during April 2006: Particle chemical composition, boundary layer structure, and radiative forcing, J. Geophys. Res., 115, D18208, doi:18210.11029/12009JD013391, 2010.

Warneck, P.: In-cloud chemistry opens pathway to the formation of oxalic acid in the marine atmosphere, Atmos. Environ., 37, 2423-2427, 2003.

Xie, M., Wang, G., Hu, S., Han, Q., Xu, Y., and Gao, Z.: Aliphatic alkanes and polycyclic aromatic hydrocarbons in atmospheric PM10 aerosols from Baoji, China: Implications for coal burning, Atmos. Res., 93, 840-848, 2009.

Zamora, L. M., Prospero, J. M., and Hansell, D. A.: Organic nitrogen in aerosols and precipitation at Barbados and Miami: Implications regarding sources, transport and deposition to the western subtropical North Atlantic, J. Geophys. Res., 116, D20309, doi:10.1029/2011JD015660, 2011.

Zhang, R. Y., Suh, I., Zhao, J., Zhang, D., Fortner, E. C., Tie, X. X., Molina, L. T., and Molina, M. J.: Atmospheric new particle formation enhanced by organic acids, Science, 304, 1487-1490, 2004.

Zhang, X. Y., Gong, S. L., Shen, Z. X., Mei, F. M., Xi, X. X., Liu, L. C., Zhou, Z. J., Wang, D., Wang, Y. Q., and Cheng, Y.: Characterization of soil dust aerosol in China and its transport and distribution during 2001 ACE-Asia: 1. Network observations, J. Geophys. Res.-Atmos., 108, 4261, doi:10.1029/2002JD002632, 2003. 